Uniwersytet im. A. Mickiewicza, Poznań

\title{
Wokół problemu definicji mniejszości narodowych
}

Krio westia mniejszości narodowych, politycznych, językowych, wyznaniowych i rasowych pozostaje w centrum uwagi zarówno socjologów, jak i kulturoznawców, politologów, wreszcie prawników. To, że problem mniejszości jest obiektem zainteresowania przedstawicieli tak wielu dyscyplin, powoduje znaczące zamieszanie terminologiczne w zakresie podstawowych kategorii tego pola badawczego. W literaturze, w pierwszym rzędzie socjologicznej, spotyka się wiele klasyfikacji i typologii grup mniejszościowych ${ }^{1}$. Najczęściej podstawą wyróżnienia mniejszości jest rodzaj integracji grupy mniejszościowej. Wyróżnia się zazwyczaj przy tej okazji mniejszości wyodrębnione ze względu na kryteria: terytorialno-kulturowe, kulturowo-ideologiczne, biologiczne, fizjologiczne, psychiczne, wreszcie mniejszości mające charakter grup interesów. Najczęściej podstawą wyróżnienia mniejszości są: język, zwyczaje, style życia, tradycje. Wiąże się z tym najczęściej kryterium terytorialne, gdyż tego typu mniejszości bardzo często, choć nie zawsze, zamieszkują określone terytorium, w obrębie jednego lub kilku państw ${ }^{2}$. W tym miejscu wypada zwrócić uwagę, iż istnienie państwa ma konstytutywne znaczenie dla wyodrębnienia mniejszości. Państwo bowiem posia-

G. Simmel, Socjologia, Warszawa 1975, s. 300 i n.; R. E. Park, Human Migration and the Marginal Man, „The American Journal of Sociology” 1927-28, t. 33, s. 881-893; Van den Berghe, The Ethnic Phenomenon, New York-Oxford 1981; R. König, Soziologie, Frankfurt a M. 1958, s. 304; K. Kwaśniewski, Socjologia mniejszości a definicja mniejszości narodowej, „Sprawy Narodowościowe - Seria Nowa” 1992, t. I, z. 1, s. 9 i n.; T. Paleczny, Mniejszość jako socjologiczna kategoria analizy, „Studia Socjologiczne” 1994, nr 2, s. 19; tenże, Kontrowersja teoretyczna wokół socjologicznych ujęć nacjonalizmu, „Sprawy Narodowościowe - Seria Nowa” 1994, t. III, z. 2(5), s. 19; B. Williams, A class act: anthropology and the race nation across ethnic terrain, „Annual Review Anthropology” 1989, 18, s. 401-444.

2 S. Rokkan, Economy, Territory, Identity. Politics of West European Peripheries, London-Beverly Hills 1983; Minderheiten, „Forschung und Information”, Berlin 1974, B. 17, 19; P. A. F. Walter, Race and culture relations, New York 1952, s. 31. 
da określone terytorium, na którym żyją i mieszkają jego obywatele (w praktyce bardzo często bywa tak, że przebywają na tym obszarze na stałe lub przez określony czas mniejsze lub większe grupy osób nie legitymujące się obywatelstwem tego państwa lub wręcz, z różnych względów, pozbawione tego obywatelstwa). Mniejszości o charakterze terytorialno-kulturowym mogą występować w dwóch formach. Po pierwsze, jako skupisko osób żyjących w oderwaniu od macierzystej zbiorowości, gdzie przedstawiciele mniejszości są większością (np.: Słowacy w Polsce, Węgrzy w Rumunii, Polacy na Litwie). To oderwanie od macierzy następuje na skutek działania rozmaitych czynników o charakterze politycznym, militarnym, rzadziej gospodarczym, najczęściej niezależnych od woli przedstawicieli mniejszości. Po drugie, jako mniejszości etniczne, zwane także, czasami etnograficznymi, grupujące osoby wyróżniające się językiem ze zwyczajami, stylem życia i tradycjami, które nie wchodzą w skład innych suwerennych narodów, nie występują nigdzie na innych terytoriach jako większość. Przykładem mogą być Kurdowie w Iraku i Turcji, Łemkowie i Słowińcy w Polsce, Baskowie w Hiszpanii i Francji, Karaimi w Polsce i na Litwie. Występują także mniejszości o cechach regionalnych, nie mające charakteru narodowego, np.: górale tatrzańscy w Polsce, Żmudzini na Litwie ${ }^{3}$. Warto uświadomić sobie, iż pojęcie tożsamości etnicznej oznacza poczucie ciagłości z przeszłością, które jest podtrzymywane jako część autodefinicji na najgłębszym poziomie psychologicznym. W szerszym znaczeniu etniczność obejmuje kwestie wchodzące w obręb procesów tworzenia grupy, jej transformacji i trwania. Tożsamość etniczna ma charakter kulturowy i opera się na autodefinicji tworzonej na podstawie charakterystyk kulturowych danej grupy w opozycji do innych ${ }^{4}$. Tożsamość etniczną można definiować jako rozciąnięte w czasie poczucie przynależności, które wynika z samoprzypisania bądź z przypisania przez innych, względnie z obu tych przyczyn, do określonej grupy ludzi, opartej na poczuciu wspólnego pochodzenia, a także wspólnej kul-

3 A. Porębski, Europejskie mniejszości etniczne. Geneza i kierunki przemian, Kraków 1991, passim; B. Jałowiecki, Kwestia regionalna, „Studia Socjologiczne” 1992, nr 1-2, s. 45 i n.

${ }^{4}$ G. de Vos, L. Romanucci-Ross, Ethnicity: Vessel of Meaning and Emblem of Contrast, w: G. de Vos, L. Romanucci-Ross, Ethnic Identity. Cultural Continuities and Change, Mayfield-Palo Alto, passim; A. D. Smith, The politics of culture and nationalism, w: Companion Encyclopedia of Anthropology, pod red. T. Ingold, London-New York, Routledge 1994, s. 706-708. 
turowej tradycji ${ }^{5}$. Zasady wyodrębniania grupy etnicznej opierają się na sądach o wspólnotowym podobieństwie i przekonaniu o cechach (wskaźnikach) uważanych za atrybuty przynależności do danej grupy (może być to np.: kolor skóry, fizjonomia, nazwisko, wyznawana religia) ${ }^{6}$. Jednym z najbardziej oczywistych symboli tożsamości grupowej jest nazwa własna grupy, która nie musi korespondować z nazwami używanymi przez inną grupę. Grupa może posiadać jedną nazwę dla siebie, a drugą dla innych, np.: Romowie - Cyganie. W nauce funkcjonuje wiele definicji pojęcia grupy etnicznej. Jedne podkreślają obiektywny charakter i skład grupy etnicznej inne zwracają uwagę na rolę świadomości i samoprzypisania jako elementu konstytuującego grupę etniczną. Próbą połączenia tych stanowisk jest umieszczenie grupy w perspektywie historycznej i symboliczno-kulturowej ${ }^{7}$. Podkreśla się przy tym, że atrybutami grupy etnicznej są: własna nazwa zbiorowa, mit wspólnego pochodzenia, podzielana przez członków grupy historyczna pamięć, elementy wspólnej kultury, poczucie solidarności. Sprzyjają wyróżnieniu grupy etnicznej takie elementy jak: religia, zwyczaje czy język. W literaturze podkreśla się, że dla trwania grupy ważniejszy jest mit posiadania wspólnych przodków niż faktyczne ich posiadanie, a pamięć historyczna może być oparta na mi$\mathrm{cie}^{8}$. Także przywiązanie do danego terytorium lub miejsca niekoniecznie musi wynikać z kryteriów obiektywnych, lecz może być oparte na subiektywnych przekonaniach. Zauważa się, że grupa etniczna może przetrwać połączona duchową więzią, nawet gdy oddzielona jest od swojego terytorium $^{9}$.

5 E. Roosens, The Primordial Nature of Origins in Migrant Ethnicity, w: The Anthropology of Ethnicity. Beyond Ethnic Groups and Boundaries, pod red. H. Vermeulen, C. Govers, Amsterdam 1994, s. 84; por. także Creating Ethnicity, London 1989, passim; E. Shils, Primordial, personal, ascred and civil ties, „,British Journal of Sociology" 1957, nr 7, s. 113-145; C. Geertz, The Integrative Revolution: Primordial Sentiments and Civil Polities in the New States, w: C. Geertz, The Interpretation of Cultures, New York 1973, s. 255-310.

6 D. L. Horowitz, Ethnic Identity, w: Ethnicity. Teory and Experience, pod red. N. Glazer, D. P. Moynihan, Cambridge, Massachussetts Harvard University Press, s. 112 .

7 A. P. Cohen, The Symbolic Construction of Community, London 1985, s. 72 i n.; F. Barth, Introduction, w: Ethnic Groups and Boundaries, pod red. F. Barth, Bergen-Oslo, London 1969, s. 7 i n.

8 M. Chapman, The Celts, New York 1992, s. 32.

9 L. Holly, Kulturowe tworzenie tożsamości etnicznej, w: Sytuacja mniejszościowa i tożsamość, pod red. Z. Macha, A. K. Palucha, Zeszyty Naukowe Uniwersytetu Ja- 
W literaturze, a zwłaszcza w publicystyce naukowej, mniejszość narodowa zazwyczaj rozumiana jest jako część ludności państwa, należąca do innego narodu niż naród tworzący państwo. Część badaczy oraz większość polityków skłonna jest traktować mniejszość etniczną bądź grupę etniczną jako zbiorowość, która nie jest narodem, ale posiada własną kulturę, przeświadczenie o wspólnym pochodzeniu, a częstokroć posiada własne terytorium nie mające statusu państwa ${ }^{10}$. Odmawianie grupom legitymującym się własną kulturą, językiem i przeświadczeniem o wspólnym pochodzeniu i, nader często, zamieszkującym w zwarty sposób określone terytorium miana „narodu”, i przyznanie im jedynie statusu „mniejszości etnicznych” bądź „etnograficznych”, ewentualnie „narodowości” wynika z przesłanek politycznych, częstokroć nacjonalistycznych $^{11}$. Postawa taka cechowała wielu polityków i uczonych byłego ZSRR. Uznanie pewnej grupy za naród, a nie za grupę etniczną ma istotne i daleko idące konsekwencje polityczne. Tylko naród, nie zaś grupa etniczna, może upominać się o swe prawa do suwerenności.

W gruncie rzeczy nie wypracowano żadnych kryteriów pozwalających rozróżnić naród od mniejszości narodowych bądź etnicznych. Najrozsądniejsze wydaje się przyjęcie tezy, iż mniejszość narodowa to taka część ludności państwa, która legitymując się własną kulturą, przeświadczeniem o wspólnym pochodzeniu, często językiem, religią i zamieszkująca (ale nie zawsze) wspólne terytorium, różni się od narodu tworzącego określone państwo. Oczywiście, teza ta okaże się nieprawdziwa lub nie do końca prawdziwa w odniesieniu do państw wielonarodowych.

Według koncepcji naturalistycznej, naród traktowany jest jako grupa genetyczna, uwarunkowana właściwościami środowiska geograficznego, w jakim zamieszkiwała. W koncepcji politologicznej naród jest wspólnota polityczną, tożsamą z państwem. Każde państwo zabiega o ukształtowanie w swoich ramach narodu. Zgodnie z koncepcją kulturową, naród jest ukształtowaną w toku rozwoju historycznego społecznością, której członkowie uczestniczą we wspólnej kulturze narodowej obejmującej język,

giellońskiego MXXIX, 1992, s. 212; F. Barth, Introducion, s. 7 i n.; A. P. Cohen, The Symbolic Contruction, s. 85 i n.; A. D. Smith, National Identity, London 1991, s. 20.

10 A. D. Smith, Nations and Nationalism in a Global Era, Cambridge 1995, S. $56-57$.

11 A. Kłoskowska, Kultury narodowe u korzeni, Warszawa 1996, s. 32-51; A. D. Smith, The Ethnic Origins of Nations, Oxford 1986 s. 25; W. Connor, Ethnonationalism. The Quest for Understanding, Princeton 1994, s. 102-103. 
obyczaje, sztukę i naukę, działalność gospodarczą, tradycje i inne formy aktywności ${ }^{12}$. W tym ujęciu naród jest wspólnotą kultury. Wspólnota ma formę nie tylko faktyczną, lecz także ideologiczną, gdyż w tworzeniu kultury członkowie narodu kierują się pewnymi ideałami narodowymi, wizją, ideologią, aspiracjami w zakresie różnych dziedzin kultury ${ }^{13}$. Tak więc $\mathrm{w}$ tym ujęciu świadomość narodowa jest istotnym elementem konstytuującym naród w obrębie zbiorowości ludzi zamieszkujących określone terytorium.

Uznając, że naród ukształtował się w płaszczyźnie kultury, podkreśla się, że jest on w przeciwieństwie do państwa zbiorowością społeczną o charakterze kulturowej wspólnoty. Według E. Gellnera i B. Andersona, naród jest konstrukcją ideologiczną, a jego powstanie ma na celu odnalezienie związków między samookreślającą się kulturowo grupą a państwem. Obaj badacze, mimo dzielących ich różnic, genezę współczesnych narodów wiążą z rozwojem uprzemysłowienia i homogenizacją kultury oraz z przemianami społecznymi i kulturowymi. W tym ujęciu naród nie jest synonimem społeczeństwa, w tym także społeczeństwa obywatelskiego ${ }^{14}$. Konstatacje E. Gellnera i B. Andersona, akcentujące związek między państwem a narodem nie wyjaśniają jednak kwestii mniejszości narodowych i grup etnicznych, chyba że ktoś przyjąłby, że narodem jest tylko taka grupa legitymująca się wspólnym pochodzeniem, językiem, dziedzictwem kulturowym itp., która utworzyła państwo. Jeśliby przyjąć, że przedstawiciele takiej grupy mieszkają na obszarze, na którym inny naród utworzył państwo, to wtedy są mniejszością narodową na tym terenie. Warto jednak zauważyć, iż w nauce polskiej dość mocno ugruntowany jest pogląd o niezależności narodu od państwa, które nie jest niezbędnym czynnikiem jedności narodowej ${ }^{15}$. Zauważa się także, iż naród jest synonimem spo-

12 J. Wiatr, Naród i państwo. Socjologiczne problemy kwestii narodowej, Warszawa 1973, s. 189-207; por. także J. Sobczak, Podstawy wiedzy o państwie i prawie, Poznań 2002, s. 28-29; A. Kłoskowska, Teoretyczne spory na temat narodu a ujęcie kulturologiczne i indywidualizujace, "Przegląd Zachodni” 1994, 4(273), s. 1-8.

13 S. Ossowski, Więź społeczna i dziedzictwo krwi, w: Dzieła, t. 2, Warszawa 1966; tenże, Analiza socjologiczna pojęcia ojczyzny, w: Dzieła, t. 3, Warszawa 1967, s. 210 i n.; tenże, O ojczyźnie i narodzie, Warszawa 1984.

14 E. Gellner, Narody, Nacjonalizm, Warszawa 1991, s. 14-16 i 65; B. Anderson, Wspólnoty wyobrażone. Rozważania o źródłach i rozprzestrzenianiu się nacjonalizmu, Kraków-Warszawa 1997, s. 25 i n.; Z. Ziembiński, Socjologiczne pojmowanie naro$d u$, ,Sprawy Narodowościowe - Seria Nowa” 1995, t. IV, z. 2(7), s. 165-175.

15 F. Znaniecki, Współczesne narody, Warszawa 1990, s. 25 i n. oraz 122 i n.; koncepcję narodu F. Znanieckiego omawiają m.in.: J. Szacki, Naród w socjologii Znaniec- 
łeczeństwa, w tym także społeczeństwa obywatelskiego, we wszystkich jego znaczeniach. Wielu badaczy posługuje się pojemną koncepcją narodu państwowego na określenie wczesnej formy zbiorowości niezróżnicowanej jeszcze etnicznie, ale podporządkowanej jednemu państwu, którego administracyjna polityka prowadzi do stopniowego ujednolicenia kultury tej zbiorowości ${ }^{16}$. Pojęcie narodu państwowego oraz zbliżone do niego pojęcie narodu kierowanego przez państwo nie są równoznaczne z narodem obywatelskim i nie implikuje demokratycznego charakteru państwa. Określenie „naród obywatelski” wiąże się z koncepcją społeczeństwa obywatelskiego, sformułowaną przez T. Hobbesa oraz rozwiniętą przez G. W. Hegla udzielającego szerokich instytucjonalnych gwarancji systemowi stosunków ludzkich. Według koncepcji A. D. Smitha, istnieją dwa aspekty narodu: terytorialno-obywatelski i etniczno-genealogiczny, które występują w różnych proporcjach w konkretnych przypadkach oraz wywodzą się z odmiennych typów etnicznych wspólnot i procesów narodowotwórczych. Naród, zdaniem A. D. Smitha, jest konstrukcją złożoną z wzajemnie powiązanych komponentów etnicznych, kulturowych, terytorialnych, ekonomicznych i prawno-politycznych. Koncepcja terytorialno-obywatelska narodu zakłada, iż jest on kulturową i polityczno-prawną wspólnota, posiadającą swoje historyczne terytorium, zakładającą prawną

kiego, „Przegląd Polonijny” 1983, nr 4 oraz W. Markiewicz, Florian Znaniecki jako socjolog narodu, w: Florian Znaniecki i jego rola w socjologii, pod red. A. Kwileckiego, Poznan 1975; J. Szacki, Znaniecki: dylemat determinizmu i twórczości, „Kultura i Społeczeństwo" 1989, nr 3, s. 13-21.

16 J. Bardach, Od narodu politycznego do narodu etnicznego, „Kultura i Społeczeństwo" 1993, nr 4, s. 3-16; tenże O powstaniu nowoczesnego narodu litewskiego, w: O dawnej i niedawnej Litwie, Poznań 1988, s. 247-256. Por. w tym przedmiocie stanowisko L. Greenfeld, Nationalism. Five Roads to Modernity, Cambridge-Harvard 1992, s. 3 i 13 oraz L. Greenfeld, D. Chirat, Nationalism and Aggression, „Theory and Society" 1994, nr 1, s. 82 i n. Zob. także E. Shils, Naród narodowość i nacjonalizm a społeczeństwo obywatelskie, „Sprawy Narodowościowe - Seria Nowa” 1996, t. V, z. 1(8), s. 9-30. Zwraca także uwagę stanowisko Ch. Tilly, który posługując się sformułowaniem „Naród kierowany przez państwo” podkreśla znaczenie czynników kulturowych w kształtowaniu narodu, por. Ch. Tilly, State and Nationalism in Europe 1492-1992, „Theory and Society” 1994, nr 1, s. 133-140, także Ch. Tilly, Formowanie się państw narodowych w Europie Zachodniej, w: Władza i społeczeństwo, pod red. J. Szczupaczyńskiego, t. 2; Antologia tekstów z zakresu socjologii polityki, Warszawa 1998, s. 20. Zob. ciekawe uwagi H. Kubiaka, Przyczynek do sporu o nature i przyszlość narodu-państwa, w: Idee a urzadzanie świata spotecznego. Ksiega jubileuszowa dla Jerzego Szackiego. Zbiór rozpraw pod red. E. Nowickiej i M. Chatubińskiego, Warszawa 1999, s. 211-222. 
i polityczną równość wszystkich członków oraz posiadającą wspólną obywatelską ideologię, która dostarcza wzorców zachowań, kształtuje aspiracje i jest podkładem idei członków tej społeczności. W myśl koncepcji etniczno-genealogicznej naród ujmowany jest jako jedna wielka fikcyjna rodzina, w której dominuje endemiczna kultura, tradycja i język. Etniczny model określa członkostwo narodu, jako organicznie nieuniknione. Jednostka jest członkiem narodu bez względu na to, czy pozostaje we wspólnocie, czy też opuszcza ją na rzecz innej ${ }^{17}$.

Podkreśla się, za Ferdinandem Tönniesem, że naród jest wspólnotą, a nie społeczeństwem, gdyż dominują w jego łonie więzy pokrewieństwa, braterstwa i sąsiedztwa, przy czym głównym instrumentem kontroli społecznej jest zwyczaj i tradycja, a podstawą identyfikacji - świadomość zbiorowa $^{18}$. W przeciwieństwie do Tönnniesa Max Weber-także widzący w narodzie wspólnotę - uważał, że jest to wspólnota wartości, z którą nierozłącznie wiąże się potrzeba odniesienia jednostki do postaw ustanawiających te wartości. W koncepcji Webera, naród występuje w kontekście wielkich struktur społecznych: państwa i społeczeństwa, ale nie jest $\mathrm{z}$ nimi utożsamiany ${ }^{19}$.

Według innych koncepcji, wyróżnić należy definicje rasowo-antropologiczne, psychologiczno-kulturowe, etatystyczne i wreszcie historyczne. Definicje rasowo-antropologiczne widzą w narodzie wspólnotę „pochodzenia” bądź „krwi”; psychologiczno-kulturowe kładą nacisk na konieczność wytworzenia przez naród własnej kultury duchowej i materialnej oraz pojawienie się świadomości więzi narodowej i poczucia odrębności. W ujęciach etatystycznych akcentuje się związki między narodem a państwem, utożsamiając naród z obywatelami państwa i wskazując, że każdy naród dąży do stworzenia własnego państwa, aczkolwiek nie każdemu udaje się ten cel osiągnąć. Definicje historyczne pojmują naród jako złożony wytwór procesów historycznych.

W Polsce wielu badaczy, w ślad za Jerzym Szackim, podkreśla, że w rozważaniach nad narodem pojawiają się dwa sposoby myślenia. Pierw-

17 A. D. Smith, National Identity, s. 14 i n.

18 A. Przestalski, Lud, naród i wola w systemie socjologicznym Ferdinanda Tönniesa, „Sprawy Narodowościowe - Seria Nowa” 1995, t. IV, z. 1(6), s. 9-16.

19 M. Weber, Gospodarka i społeczeństwo. Zarys socjologii rozumiejacej, Warszawa 2002, s. 315 i n.; tenże The Nation, w: From Max Weber: Essays in Sociology, London 1948. Zob. także D. Praszałowicz, Naród i nacjonalizm w myśli Maxa Webera, „Przegląd Polonijny” 1995, nr 1, s. 11. 
szy z nich akcentuje fakt, że naród jest zbiorowością zamieszkującą wspólne terytorium i podlegającą tym samym prawom. Drugi podkreśla, że narodem jest przede wszystkim historycznie ukształtowana wspólnota kulturowa $^{20}$. W klasycznej literaturze prawniczej, socjologicznej i politologicznej formułowane są definicje genetyczne i strukturalne narodu. W definicjach genetycznych określa się naród poprzez wskazanie czynników, które złożyły się na jego powstanie. W definicjach strukturalnych wskazuje się cechy, które „na ogół” charakteryzują grupę społeczną zwaną narodem. W zależności od tego, jakie cechy brane są pod uwagę przez definiującego, mówi się o definiowaniu narodu w kategoriach materialnych, politycznych, kulturowych oraz świadomościowych.

Bardzo często definicje narodu mają charakter instrumentalny, służąc doraźnym celom politycznym bądź dając podstawę do odmowy określonym grupom prawa do statusu narodu albo też przeciwnie - podnosząc pewne społeczności do poziomu narodu (tak czynili np. Niemcy w czasie II wojny światowej, tworząc ,naród góralski” - Goralenvolk). Niejednokrotnie definiując „naród” posługiwano się swoistą metaforyką, uciekając się do intelektualnej prowokacji bądź też formułując w definicji apele czy programy polityczne ${ }^{21}$.

W nowszej literaturze przedmiotu mówi się obecnie raczej o podejściach teoretycznych, stylach badań i koncepcjach ${ }^{22}$. Podejście ,prymordialistyczne" (występujące w wariancie psychologicznym i socjologicznym) zakłada bytową pierwotność narodu i grup etnicznych ${ }^{23}$. W podejściu

20 J. Szacki, Koncepcja narodu w socjologii i historii, w: J. Szacki, Dylematy historiografii idei oraz inne szkice i studia, Warszawa 1991, s. 360, s. 351-363 (pierwodruk tekstu pt.: Koncepcja narodu w socjologii $i$ historii: podobieństwa $i$ różnice, „Przegląd Powszechny” 1986, nr 7, s. 182-193; tenże, Kłopoty z pojęciem narodu, w: Humanistyka przełomu wieków, pod red. J. Kozieleckiego, Warszawa 1999, s. 153-154 oraz to samo „Odra” 1999, s. 11-16.

21 M. Waldenberg, Narody zależne i mniejszości narodowe w Europie Środkowo-Wschodniej. Dziej konfliktów i idei, Warszawa 2000, s. 20-21; zob. również J. Szacki, Historia myśli socjologicznej, część pierwsza, Warszawa 1983, s. 144; tenże, Historia myśli socjologicznej. Wydanie nowe, Warszawa 2002, s. 173 i n.

22 J. Kurczewska, Naród w socjologii i ideologii polskiej, Warszawa 1996. Por. także W. Deutsch, Nationalism and Social Communication, Cambridge 1966, s. 97; W. Connor, Ethnonationalism, s. 102 i n.

${ }^{23}$ O podejściu prymordialistycznym w ujęciu psychosocjologicznym zob. C. Geertz, The Interpretation of Culture, New York 1973, s. 255-310; tenże Ethnic Conflict: three alternative terms, „Common Konwledge” 1993, t. 2, s. 54-55; E. Shils, Primordial, personal, op. cit., s. 113 i n.; F. Barth (red.), Ethnic Groups, op. cit., passim. 
„obiektywistycznym” usiłuje się scharakteryzować naród przez wyliczanie jego atrybutów i $\operatorname{cech}^{24}$. Podejście „subiektywistyczne” akcentuje problematykę samoświadomości oraz tożsamości narodowej ${ }^{25}$. Koncepcja „komunikacyjna” widzi w narodzie efekt procesów komunikacyjnych określonej społeczności ${ }^{26}$. Podejście ,instrumentalistyczne" zasadza się na przekonaniu, że naród to wytwór nacjonalizmu ${ }^{27}$.

24 A. D. Smith, Nations and Nationalism, op. cit., s. 56 i n.

25 W. Connor, Ethnonationalism, s. 105 i n.

26 W. Deutsch, Nationalism, s. 99; por. także A. Sadowski, Pojęcie grupy etnicznej w socjologii, „Studia Socjologiczne” 1973, nr 4, s. 183-184; W. Pawluczuk, Światopoglad jednostki w warunkach rozpadu społeczności tradycyjnej, Warszawa 1972, s. 36; R. K. Merton, Teoria socjologiczna i struktura spoleczna, Warszawa 1982, s. 351 i n.; R. Radzik, Między zbiorowościq etnicznq a wspólnotq narodowa, Lublin 2000, s. 19 i n; tenże, Od zbiorowości etnicznej do wspólnoty narodowej. Podstawowe pojęcia uktadu etniczno-narodowego w Europie Środkowo-Wschodniej w XIX i XX wieku, „Studia Socjologiczne” 1999, nr 2, s. 32 i n.; tenże, Formowanie się narodów w Europie Środkowo-Wschodniej, „Kultura i społeczeństwo” 1993, nr 4, s. 17-34; M. Maus, Oeuvres, Edition du Minuit, Paris 1969, s. 596.

27 E. Habsbawm, Debunking Ethnic Myths, „Open Society News” 1994; tenże, Nations and Nationalism since 1780. Programme Myth, Reality, Cambridge 1990, s. 8; B. Anderson, Wspólnoty wyobrażone. Rozważania o źródłach i rozprzestrzenianiu sie nacjonalizmu, Kraków-Warszawa 1997, passim; H. Kohn, The Idea of Nationalism, New York 1945; E. Gellner, Narody, nacjonalizm, s. 11 i n., 69 i n., 161 i n. Począwszy od wystapienia E. Gellnera, badania nad narodem jako zjawiskiem socjologicznym, historycznym, politycznym i prawnym zostały zdominowane przez rozważania odnoszące się do fenomenu nacjonalizmu. Dociekania te zapoczątkował jeszcze F. Meinecke w mocno już dzisiaj zapomnianym dziele Weltbürgertum und Nationalstaat (Berlin 1908), dzieląc nacjonalizmy na ,polityczne”, ukształtowane przez wspólną historię i postulujące przekształcenie państwa we wspólnotę równoprawnych obywateli, oraz „kulturowe”, odwołujące się do wspólnoty języka, kultury i religii, dążące do swobodnego rozwoju indywidualności narodowej. Pewnym nawiązaniem do tej koncepcji na gruncie polskim były rozwiązania R. Dmowskiego, który wśród licznych więzi łączących naród wyodrębniał dwie podstawowe: po pierwsze - wspólne dzieje i współżycie ludzi w ciągu następujących po sobie pokoleń pod jedną władzą; po drugie - wspólność życia duchowego, opartą na języku. (por. R. Dmowski, Zagadnienia środkowo- i wschodnio-europejskie, w: Wybór pism, Nowy York 1988, t. 3, s. 284-287). Wydarzenia polityczne sprawiły, że stanowisko R. Dmowskiego, stygmatyzowane przez niektórych publicystów naukowych jako „szowinistyczne”, poszło praktycznie w niepamięć. Wypada jednak odnotować dość dużą zbieżność poglądów R. Dmowskiego i przywołanego wyżej E. Gellnera. Bardzo popularna w USA i na zachodzie Europy dychotomiczna koncepcja podziału nacjonalizmów, wspomnianego wyżej, H. Kohna zasadza się na założeniu, że między niemieckim nacjonalizmem a nacjonalizmem Europy Środkowej istnieją podstawowe różnice. Systematyczny wykład 
Koncepcja ,instytucjonalistyczna” wychodzi z założenia, że naród jest instytucją polityczną, pozostającą w określonych relacjach do pań-

poglądów H. Kohna przedstawił L. L. Snyder, The Meaning of Nationalism, New Brunswick-New Jersey 1962, s. 118-120. Szczegółową dyskusję z koncepcjami H. Khna przeprowadza A. Kemiliäinen w pracy: Nationalism. Problems Concerning the World. The Concept and Classification, Iväskyla 1964, s. 115-142. Jakkolwiek idee H. Kohna nie są obecnie szczególnie popularne, to jednak legły one u podstaw podziału nacjonalizmu na nacjonalizm „obywatelski” i ,etniczny”. Por. w tym ostatnim względzie L. Greenfeld, Nationalism. Five Roads ... W kwestii nacjonalizmu zob. także K. Kwaśniewski, $O$ nacjonalizmie inaczej, „Sprawy Narodowościowe - Seria Nowa" 1996, t. V, z. 1(8), s. 59-82; E. Shils, Naród, narodowość i nacjonalizm a społeczeństwo obywatelskie, s. 9 i n.; J. Wiatr, Powrót do historii. Nacjonalizmy $w$ erze postkomunistycznej, „Sprawy Narodowościowe - Seria Nowa” 1994, t. III, z. 1(4), s. 9-18; K. Kwaśniewski, Konflikt etniczny, „Sprawy Narodowościowe - Seria Nowa" 1994, t. III, z. 1(4), s. 39-52; D. Langwiesche, Naród, nacjonalizm, państwo narodowe. Stan i perspektywy badań, „Sprawy Narodowościowe - Seria Nowa” 2002, z. 20, s. 56; inny przegląd badań przynosi artykuł T. Kamusella, Nacjonalizm i jego badacze (z perspektywy anglosaskiej), Przeglad literatury, „Sprawy Narodowościowe Seria Nowa” 2001, z. 18, s. 121-146; K. Jaskułowski, Co to jest nacjonalizm, „Sprawy Narodowościowe - Seria Nowa” 2001, z. 18, s. 81-92; K. Skubiszewski, Nacjonalizm w dzisiejszej Europie, „Sprawy Międzynarodowe” 1993, nr 3, s. 24; T. Sokołowski Typologia nacjonalizmów i ich przejawy, w: Nacjonalizm, konflikty narodowościowe w Europie Środkowej i Wschodniej, pod red. S. Helnarskiego, Toruń 1994, s. 39 i n.; J. Fiszer, Źródła nacjonalizmu w postkomunistycznej Europie i metody ich przezwyciężania, w: Świat i Polska u progu XXI wieku, pod red. M. Szczepaniak, Toruń 1994, s. 64 i n.; T. Paleczny, Kontrowersje teoretyczne wokół socjologicznych ujęć nacjonalizmu, „Sprawy Narodowościowe - Seria Nowa” 1994, t. II, z. 2(5), s. 19-30; W. J. Burszta, Etnonacjonalizm. Nauka $w$ poszukiwaniu sensu wydarzeń, tamże s. 31-42; G. Michałowska, Współczesny nacjonalizm a państwo, w: Państwo we współczesnych stosunkach międzynarodowych, pod red. E. Haliżak, Warszawa 1995, s. 17; G. Mojsiewicz, Złożoność kwestii narodowej i nacjonalizmu, w: Obcy-Sasiedzi - Niechciani partnerzy, pod red. K. Glass, Poznań-Torun 1995, s. 35, i n.; A. Bromke, Nacjonalizm w nowoczesnym świecie, w: Nacjonalizm, konflikty, pod red. S. Helmarskiego, s. 9 i n.; J. Berlin, Nacjonalizm. Zlekceważona potega, w: tegoż Dwie koncepcje wolności, Warszawa 1991, s. 207-214. Ciekawą koncepcję nacjonalizmów, chociaż opartą na dość ubogiej i nie do końca reprezentatywnej literaturze przedmiotu - na co zwracałem uwagę autorowi w recenzji wydawniczej-prezentuje praca S. Wojciechowskiego Nacjonalizm w Europie Środkowo-Wschodniej, Wrocław 1998, s. 15-52. Niezwykle pesymistyczną wizję nacjonalizmu jako siły głęboko destrukcyjnej, rozsadzającej układy polityczne i próby budowania światowego ładu kreśli D. P. Moynihan, mocno podkreślając, iż w nauce brak zgodności co do takich podstawowych terminów jak: ,naród”, ,grupa etniczna”, „mniejszość narodowa” czy „,narodowość". Por. D. P. Moynihan, Pandaemonium. Ethnicity in International Politics, Oxford 1994, s. 107-182. 
stwa $^{28}$. Wreszcie „konstruktywiści” widzą w narodzie element hierarchii tożsamości zbiorowej ${ }^{29}$.

Szczególnie interesujące wydają się te rozwiązania, które podejmują próby sformułowania definicji narodu poprzez wyliczenie elementów składających się na to pojęcie. Według G. Kellasa, naród tworzą czynniki o charakterze obiektywnym: terytorium, język, religia, wspólne pochodzenie, aczkolwiek nie wszystkie występują w odniesieniu do każdego narodu, oraz czynniki subiektywne: świadomość odrębności narodowej i demonstrowane przez ludzi przywiązanie do niej ${ }^{30}$. M Ryan stwierdza, że naród cechuje „świadomość narodowa”, język, doświadczenie historyczne, geografia, religia i ogólne czynniki kulturowe ${ }^{31}$. Zdaniem J. Krejciego i V. Velimskyego, naród określają czynniki obiektywne: terytorium, państwo, kultura, historia oraz mająca charakter subiektywny świadomość narodowa ${ }^{32}$.

Od definicji narodu odchodzi wielu badaczy w tym w Polsce Marek Waldenberg, który proponuje zastąpienie definicji modelem bądź typem idealnym narodu. Jego zdaniem, na takowy model składają się: wspólny język; terytorium, na którym mieszka określona zbiorowość lub jej znacząca część i które uważa ona za swoją ziemię ojczystą; dziedzictwo kulturowe, z którym znaczna część zbiorowości identyfikuje się jako z własnym; partycypowanie w kulturze narodowej; wspólna dla członków takiej społeczności dość bogata symbolika, a więc wspólny zasób uczuć i myśli; przeświadczenie o wspólnym pochodzeniu etnicznym większości przedstawicieli zbiorowości; znaczne poczucie wspólnoty istniejące w ramach takiej społeczności między ludźmi różnych klas i warstw społecz-

28 R. Brubaker, Nationalism Reformated. Nationhood and the National Question in the New Europe, Cambridge 1996 (wyd. polskie: Nacjonalizm inaczej. Struktura narodowa i kwestie narodowe w nowej Europie, Warszawa-Kraków 1998, s. 15-20 i 22-25); tenże, Citizenship and Nationhood in France and Germany, Cambridge-Harvard 1992; M. Mann, The Sources of Social Power, t. II, Cambridge 1993; A. Giddens, The Nation State and Violence, Cambridge 1985, passim.

${ }^{29}$ F. Barth, Enduring and Emerging Issues in the Analysis of Ethnicity, w: The Anthropology of Ethnicity, pod red. H. Vermeulen, C. Govers, op. cit.; A. Cohen, Two Dimentional Man, London 1974.

30 G. Kellas, The Politics of Nationalism and Ethnicity, London 1991, s. 2-3.

31 M. Ryan, Nationalism, Ethnicity and European Unity: An Irish Perspective, bmrw (powielony tekst wykładu wygłoszonego w Oxfordzie 14 listopada 1993 r.).

32 J. Krejči, V. Velimsky, Ethnic and Political Nations in Europe, London 1981, s. $44 \mathrm{i} \mathrm{n}$. 
nych; istnienie w przeszłości lub obecnie państwa traktowanego jako swoje bądź wola i dążenie do stworzenia państwa, ewentualnie chęć uzyskania autonomii ${ }^{33}$.

Do mniejszości wyodrębnionych z uwagi na kryterium terytorialno-kulturowe należą także grupy etniczne o rodowodzie migracyjnym, np. Polacy w USA bądź we Francji, Koreańczycy w Rosji. Praktycznie każda zbiorowość narodowa ma swoje emigracyjne odłamy. Zdarzają się całe państwa składające się w mniejszym lub większym stopniu z takich mniejszości ${ }^{34}$.

W literaturze podkreśla się, że status mniejszości etnicznej może nabyć każda grupa wyodrębniająca się ze społeczności z uwagi na różnice: rasowe, językowe i kulturowe bądź pochodzenie narodowe. Termin „mniejszości etniczne” jest z natury rzeczy wieloznaczny, gdyż każda grupa etniczna może znaleźć się w mniejszości w określonych warunkach historyczno-geograficznych. Każda zbiorowość imigracyjna mająca status grupy etnicznej może się okazać mniejszością, gdy z racji niepełnej asymilacji zajmuje podrzędne miejsce w strukturze społeczeństwa przyjmującego. (Taki charakter miały zbiorowości Polaków i Niemców w Kazachstanie czy zbiorowości Rosjan we współczesnej Estonii.) Mniejszości etniczne cechuje zwykle kilka poziomów organizacyjnych począwszy od rodzinnej, sąsiedzkiej lokalnej, przyjmującej czasem postać getta etnicznego czy dzielnicy etnicznej (zjawisko często spotykane w USA oraz w Niemczech i Francji w formie dzielnic murzyńskich, arabskich, tureckich) po ogólnokrajową, a czasem globalną ${ }^{35}$.

Termin „mniejszość etniczna” używany jest najczęściej w trzech znaczeniach. Po pierwsze, na określenie zbiorowości skupiających ludzi przekonanych o wspólnocie pochodzenia i połączonych silnie umotywo-

33 M. Waldenberg, Narody zależne, s. 23-24. Stanowisko Waldenberga wydaje się zbieżne z poglądami B. Andersona, według którego wspólnoty etniczne i narodowe nie powinny być rozpatrywane przez pryzmat ich domniemanej ,autentyczności” lub „fałszywości”, ale z punktu widzenia stylu, w jakim są wyobrażone jako zbiorowe konstrukty wyobraźni, gdyż naród jest „wyobrażoną wspólnotą polityczną”, por. B. Anderson, Wspólnoty wyobrażone, op. cit. s. 15 i n.

34 T. Paleczny, Mniejszość jako socjologiczna kategoria analizy, „Studia Socjologiczne” 1994, nr 2, s. 11 i n.; K. Kwaśniewski, Socjologia mniejszości, s. 16-19.

35 K. Kwaśniewski, Zderzenie kultur, Warszawa 1982, s. 32 i n., 199-201, 306-313; R. A. Schermerhorm, Comparative Ethnic Relations, New York 1970, s. 192 i n., O. C. Cox, Caste, Class and Race, New York 1948, s. 353 i n.; G. E. Simpson, J. N. Yinger, Racial and Cultural Minorities, New York 1958, s. 26 i n. 
waną wiarą we wspólną etnogenezę oraz, w konsekwencji, zajmowanie wyjątkowego (podrzędnego lub wyróżniającego) miejsca w hierarchii społecznej. Członkostwa takich grup się nie wybiera, ale jest wynikiem urodzenia i pochodzenia. W tym znaczeniu mniejszością etniczną jest część innego narodu bądź nawet cały naród żyjący na terytorium państwowym innego narodu ${ }^{36}$. Po drugie, terminu „mniejszość etniczna” używa się w odniesieniu do tych zbiorowości połączonych wiarą we wspólne pochodzenie, którym nigdy nie udało się osiagnąć statusu społeczeństw polityczno-obywatelskich i które nigdy nie miały własnego państwa (np.: Romów, Basków, Kurdów). W myśl niektórych poglądów, mniejszość etniczna, w tym rozumieniu to zbiorowość, która nie jest „w pełni dojrzałym narodem", ale ma daleko posuniętą autonomię i odrębność kulturową, a istnieje i funkcjonuje w obrębie społeczeństwa obywatelskiego bądź państwa narodowego stworzonego i kontrolowanego przez zbiorowość dominującą ${ }^{37}$. Po trzecie, mniejszość etniczna to grupa imigrantów, której członkowie indywidualnie lub zbiorowo przenieśli się z jednego terytorium narodowego, ewentualnie państwowego, do drugiego, gdzie przechodzi proces reorientacji świadomościowej i kulturowej, polegającej na stopniowym nabywaniu cech kultury kraju osiedlenia. W tym układzie ka-

36 M. Weber, Wirtschaft und Gesellschaft. Grundriss der verstehenden Soziologie, Tübingen 1922, passim; N. Glaser, D. Moynihan (red.), Ethnicity. Theory and Experience, Cambridge 1975, passim. W literaturze przedstawiono, jak zwykło się podkreślać, użyteczną typologię stopni etnicznego zorganizowania, dzięki której można scharakteryzować różne warianty grup etnicznych, a mianowicie: kategorii etnicznej, układu etnicznego, związku etnicznego i społeczności etnicznej. Por. D. Handelman, The Organization of Ethnicity, „Ethnic Groups” 1977, 1, s. 187-200, cyt. za W. J. Burszta, Konteksty etniczności, „Sprawy Narodowościowe - Seria Nowa” 1997, t. VI, z. 1(10), s. 158-159. W myśl tej typologii, kategorią etniczną (ethnic category) jest wspólnota słabo zorganizowana, do której przynależność oparta jest na znajomości przez określoną jednostkę swojego pochodzenia. W układzie etnicznym jego członkowie są świadomi swojej przynależności etnicznej i poprzez ten pryzmat postrzegają obcych. Członkowie związku etnicznego mają poczucie wspólnoty interesów i są w posiadaniu organizacyjnego aparatu służącego wyrażaniu tej wspólnoty. Związek ten może przybrać postać partii politycznej, organizacji, kościoła bądź związku wyznaniowego, klubu narodowego. Społeczność etniczna odznacza się najwyższym stopniem zorganizowania. Posiada ona własne terytorium, chociaż granice jego są zmienne. W kwestii sytuacji społecznej ludzi stojących na pograniczu dwóch grup etnicznych zob. ciekawe studium K. Kwaśniewskiego Marginalność etniczna i narodowa, „Sprawy Narodowościowe - Seria Nowa” 2000, z. 16-17, s. 7-26.

37 A. Porębski, Europejskie mniejszości etniczne. Geneza i kierunki przemian, Kraków 1991, s. 17 i n. 
żda grupa etniczna może, w zależności od sytuacji, raz występować w pozycji mniejszości, a raz zajmować pozycję dominującą ${ }^{38}$.

Przy tej okazji wypada zauważyć, że w nauce funkcjonują różnorodne definicje mniejszości. Wyróżnia się wśród nich definicje nominalne (ilościowe) zasadzające się na ocenie liczebności dwóch grup społecznych, z których mniejsza liczbowo jest właśnie mniejszością. Definicje normatywne, chętnie przywoływane w naukach prawnych i politycznych, kładą nacisk na obywatelski charakter określonej grupy bądź kategorii społecznej. Definicje socjologiczne opierają się na różnych kategoriach wyodrębnienia mniejszości. W pierwszym rzędzie jest to liczebność grupy ustalona w sposób relatywny w stosunku do innej grupy. Mniejszość może w tej sytuacji liczyć kilka osób, ale także kilkaset tysięcy. Bardzo często kryterium wyodrębnienia mniejszości w definicjach socjologicznych są odrębności fizyczne bądź kulturalne (kolor skóry, język, religia, obyczaje). Czasem podstawą wyodrębnienia mniejszości bywa istnienie więzi społecznej między jej członkami, niekiedy ograniczona autonomia grupy, interes grupowy, charakter członkostwa oparty na urodzeniu i pochodzeniu ${ }^{39}$. Niekiedy akcentuje się historyczno-symboliczny charakter mniejszości. Do klasycznych definicji mniejszości należą: relatywno-kontekstowe, deskryptywno-atrybutywne, intersubiektywne i autoidentyfikacyjne. W definicjach relatywno-kontekstowych mniejszość wyróżniana jest ze względu na relacje łączące ją z dominującą większością i z uwagi na czynniki i kryteria stanowiące o jej odrębności. W definicjach deskryptywno-atrybutywnych wyróżnia się pięć cech, które musi posiadać grupa mająca charakter mniejszości. Należą do nich: określone cechy fizyczne bądź kulturowe odróżniające członków tej grupy od innych, nierówne traktowanie (zarówno dyskryminacja, jak i uprzywilejowanie), przymusowy charakter członkostwa, silne poczucie solidarności grupowej, wreszcie wysoki stopień endogamii, tj. nakazu zawierania związków małżeńskich tylko wewnątrz grupy ${ }^{40}$. W definicjach opartych na kryterium intersubiektywnym, podkreśla się, iż cechą wyróżniającą mniejszość może być prze-

38 H. Kubiak, A. K. Paluch, Założenia teorii asymilacji, Wrocław-Gdańsk 1980, s. 55 i n.; E. K. Francis, Interethnic Relations. En Essay in Sociological Theory, New York-Oxfod-Amsterdam 1976, passim.

39 L. Wirth, The Problem of Minority Groups, w: The Science of Man in the World Crisis, pod red. R. Linton, New York 1947, s. 347 i n.; R. A. Schermerhron, These Our People, Boston 1949, s. 4 i n.

40 M. Harris, Ch. Wagley, Minorities in the New World, New York 1958, s. 4-11. 
konanie członków grupy o tym, że stanowią odrębna, mniejszościową zbiorowość $^{41}$. Odmianą tych definicji są te, które ograniczają pojęcie mniejszości do tych grup, które są w pełni świadome własnej odrębności i nierównego traktowania, ale nie potrafią bądź nie chcą wpłynąć na zmianę swojego położenia. Definicje te noszą miano definicji autoidentyfikacyjnych $^{42}$.

Zwrócić w tym miejscu wypada uwagę na fakt, że na ogół zarówno w pracach socjologicznych, jak i prawniczych nie zalicza się do kategorii mniejszości narodowych ludności tubylczej, żyjącej w danym państwie od niepamiętnych czasów, np.: aborygenów w Australii, Indian w USA ${ }^{43}$.

41 A. M. Rose, Minorities, w: International Encyclopedia of the Social Sciences, New York 1968, t. 10, s. 365.

42 A. Lijphart, Democracy in Plural Societies. A Comparative Exploration, New Haven 1977, s. 24; H. van Amersfoort, „Minority”, as a Sociological Concept, „Ethnic and Racial Studies" 1978, nr 2, s. 21 i n.

${ }^{43}$ Zdefiniowanie tej kategorii ludności nastręcza różnorodne trudności interpretacyjne. W projekcie deklaracji praw osób należących do mniejszości stwierdza się, że „ogólnie uważa się, iż ludność tubylcza, inaczej niż mniejszości, są to rodowici mieszkańcy kraju, którzy żyli tam od niepamiętnych czasów" (por. Human Right. Fact Sheet, nr 18, marzec 1992, United Nations Centre for Human Rights, Geneve, s. 8-19, cyt. za K. Kwaśniewski, Integracja europejska jako zagadnienie międzynarodowe, „Sprawy Narodowościowe - Seria Nowa” 1993, t. II, z. 1(2), s. 34. Według. T. Eriksena i W. J. Burszty pojęcie ludy tubylcze (miejscowe) to określenie ,stosowane w odniesieniu do pierwotnych mieszkańców danego terytorium, którzy są obecnie pozbawieni większej władzy politycznej i tylko częściowo zintegrowani z dominującym narodem, tworzącym państwo. Ludy takie pozostają częstokroć na przedindustrialnym etapie sposobu produkcji i reprezentują pozbawiony państwa system polityczny". W. J. Burszta zwraca przy tym uwagę, iż klasyfikacja jakiejś wspólnoty do grupy ludów tubylczych ma charakter arbitralny, zauważając, że pojęcie „lud tubylczy" odnosi się głównie do podmiotów kultur pozaeuropejskich. Por. W. J. Burszta, Konteksty etniczności, „Sprawy Narodowościowe - Seria Nowa” 1997, t. VI, z. 1(10), s. 154; T. H. Riksen, Ethnicity and Nationalism. Anthropological Perspectives, London 1993, s. 13-14. Zob. także w kwestii aspiracji ludów tubylczych: Minority Rights Group. World directory of Minorities, London 1990. Problemowi ochrony spraw społeczności autochtonicznej Międzynarodowa Organizacja Pracy poświęciła Konwencję nr 107 i 169. W praktyce ONZ ludom tubylczym (autochtonom) przyznaje się status odrębny od mniejszości narodowych. W aktach prawa międzynarodowego, raportach, rezolucjach i w doktrynie są one określane jako „qualified minorities”, przy czym termin ten nie jest jednak bliżej definiowany. W literaturze podkreśla się, że ludy te nie mogą być mylone z etnicznymi, religijnymi lub językowymi mniejszościami. W raporcie ONZ 1986 roku kategorię tę określono jako: „wspólnoty ludów i narodów autochtonicznych, kontynuujące własną unikalną kulturę, pozostające na własnych historycznych terytoriach i mające niedominującą pozycję w państwie”. Por. J. Sozań- 
Wypada zauważyć, że w niektórych państwach podjęto próbę ustawowego określenia nie tylko pojęć: „naród” i „mniejszość narodowa”, lecz także ustalenia dystynkcji między tymi terminami. W byłym ZSRR starannie odróżniano naród od narodowości, w RFN za „mniejszość narodową” uznaje się grupy etniczne, które mają „naród macierzysty” posiadający państwo, np.: Duńczycy. W odniesieniu do grup etnicznych, które nie posiadają poza granicami Niemiec państwa, w którym byłby narodem dominującym, w użyciu jest termin ,grupa narodowościowa”, (np. Fryzowie). Posługiwanie się tym ostatnim określeniem dalekie jest jednak od konsekwencji, gdyż inne grupy narodowościowe będące w podobnej sytuacji faktycznej, np.: Serbołużyczanie, nazywani są ludem. Należy przy tym zauważyć, że wszystkie wspomniane wyżej pojęcia wyróżniane są jedynie na szczeblu lokalnym. Natomiast na szczeblu centralnym RFN, przystępując do Konwencji ramowej o ochronie mniejszości, dokonała wyróżnienia grup etnicznych, podlegających ochronie według norm Konwencji, zaliczając do nich: Duńczyków, Fryzów, Serbów Łużyckich oraz Cyganów Sinti i Roma.

W polskich pracach socjologicznych współistnieją różne definicje mniejszości narodowej. Według J. Wiatra, mniejszością narodową jest taka ,grupa etniczna, która mieszka w państwie mającym inną większość etniczna, jeżeli owa mniejszość nie zajmuje wyodrębnionego politycznie i administracyjnie terytorium w ramach luźnej struktury federacyjnej”44. Zdaniem K. Jasiewicza, mniejszość narodowa to „grupa charakteryzująca się odmiennym poczuciem narodowym niż grupa konstytuująca dane państwo”. Jest ona „częścią jakiegoś narodu bądź sama stanowi naród, bądź też cementująca ją więź etniczna nie wiele w swoim charakterze odbiega od więzi narodowej”. W myśl tego autora, ,społeczności przedpiśmienne nie są mniejszościami narodowymi”, natomiast społeczności etnograficzne, obce etnicznie grupie większościowej, są mniejszościami, jeżeli terytorium danej grupy jest przez nią postrzegane jako ojczyzna ideologiczna w zaproponowanym przez S. Ossowskiego rozumieniu. W tej sytuacji „społeczności regionalne jako odłamy grupy większościowej o silniej-

ski, Ochrona mniejszości $w$ systemie uniwersalnym europejskim $i$ wspólnotowym, Warszawa 2002, s. 25-26. Tamże szersza literatura. Wypada zauważyć, że w doktrynie międzywojennej te grupy uznawano za mniejszości narodowe zdolne utworzyć państwo.

44 J. Wiatr, Społeczeństwo. Wstęp do socjologii systematycznej, Warszawa 1968, s. 395 . 
szych odrębnościach są mniejszościami, jeśli cechuje je kryterium posiadania w świadomości grupowej poczucia państwowego"45.

Odmienną definicję mniejszości etnicznej przedstawiła E. Nowicka, stwierdzając, że „mniejszością etniczną jest grupa etniczna, którą z inną lub innymi etnicznymi łączą stosunki podporządkowania i dominacji, przede wszystkim w zakresie pozycji prawno-politycznej, jak i ekonomicznej oraz prestiżowej”. Jednocześnie zauważyła ona, że „grupa etniczna to grupa, której członkowie uważają siebie za odrębnych i za takich są uważani przez innych". Wspomniana odrębność może dotyczyć przy tym: „kultury, języka, religii i obyczajów, genealogii historycznej postrzeganej w kategoriach wspólnoty dziejów lub wspólnoty biologiczno-rasowej, cech osobowości, zajmowanego terytorium"46.

Zdaniem K. Kwaśniewskiego, „mniejszość narodowa to kategoria lub podgrupa osób wyróżniających się odrębnością etniczną (języka, kultury, tradycji, ewentualnie także innych cech), które to osoby (lub których przodkowie) w zasadzie są allochtonami (tj. obcymi) i nie mają autonomii terytorialnej w kraju, w którym decydują się żyć, a w którym ze względu na swoją liczebność nie stanowią najważniejszego narodu państwowego. Stanowią oni zbiór osób pragnących zachować elementy tej narodowej odrębności, a czasem i przekazać je dzieciom, mimo że, jeżeli istnieje odrębne państwo narodu, z którym czują się związani, nie chcą tam wyjechać, kontakty z nim utrzymują tylko w sferze kultury, bez naruszenia politycznej lojalności wobec państwa zamieszkania"47. Z tytułu prawa do pielęgnowania swojej odrębności, o ile sami tego chcą mogą tworzyć w tym celu stowarzyszenia. Zachowują też prawo do asymilacji, zgodnie ze swą wolą, w kraju zamieszkania. W dalszym ciągu K. Kwaśniewski stwierdza, że zbiorowości etniczne, które mimo swego autochtonizmu, lub zaawansowanej autochtonizacji, znalazły się w obcym państwie narodowym, winny mieć również status mniejszości narodowych o tyle, o ile rezygnują z przeniesienia swoich roszczeń na płaszczyznę polityczną, dążenia do niepodległości lub rewizji granic. Stanowisko K. Kwaśniewskiego, jakkolwiek całkowicie zgodne z aktami prawa międzynarodowego, musi jednak budzić wątpliwości. Konsekwencją jego definicji jest

45 K. Jasiewicz, Czynniki asymilacji narodowej, „Przegląd Socjologiczny” 1977, t. 29 , s. 352 .

46 E. Nowicka, Przyczynek do teorii etnicznych mniejszości, w: Założenia teorii asymilacji, pod red. H. Kubiaka, A. K. Palucha, s. 108.

47 K. Kwaśniewski, Socjologia mniejszości, s. 56. 
bowiem odmówienie mniejszościom narodowym prawa do walki o niepodległość, o utrzymanie własnego państwa lub chociażby o autonomię. W świetle tej definicji należałoby np. odmówić statusu mniejszości: Baskom w Hiszpanii, Kurdom w Turcji i Iraku, Niemcom w Polsce przed II wojną światowa, Polakom w imperium carskim na przełomie XIX i XX wieku, Polakom we współczesnej Litwie, jeżeliby zgłosili roszczenia polityczne.

W polskiej literaturze socjologicznej pojawił się także postulat uzależnienia stopnia korzystania przez mniejszości narodowe ,ze specyficznych uprawnień i ochrony, od kilku czynników. Zakres praw i stopień ich ochrony miałby być tym większy, im bardziej zależy na tym mniejszościom, im mniej pochodzą one od dawnych zaborców bądź kolonizatorów, im bardziej ich przybycie do kraju było wynikiem przymusu lub interesu przyjmującej większości, im silniejszy jest potencjał i nacisk większości w kraju zamieszkania względem potencjału mniejszości i jej ewentualnej, zewnętrznej, narodowej grupy odniesienia, im bardziej cechy narodowe mniejszości są zgodne z samookreśleniem narodowym i im bardziej nie zmienia ona swoich pierwotnych cech kulturowych, im bardziej pogranicze kultur mniejszości i większości ma charakter stykowy a nie przejściowy, im mniejszy jest stopień autonomii, im bardziej stanowi ta mniejszość rdzenną lub zautochtonizowaną ludność danego terytorium, im większa jest liczebność i skupienie mniejszości i wreszcie - w im większym stopniu ich odrębne samookreślenie nie jest wynikiem wewnętrznych lub zewnętrznych nacisków, lecz naturalną kontynuacją"48. Propozycja ta wydaje się niezwykle ciekawa, ale nie wolno zapominać, że wprowadza ona szereg kryteriów ocennych i niedookreślonych, które przekładać się maja na bardzo wymierny status polityczny i prawny.

W prawie międzynarodowym długi czas dostrzegano jedynie problem mniejszości religijnych, ich też dotyczyły odpowiednie klauzule traktatów międzynarodowych. Postanowienia dotyczące ochrony mniejszości religijnych zawierał m.in. traktat pokojowy w Augsburgu z 1555 r., traktat wiedeński 1606 r., traktat westfalski z 1648 r., traktat oliwski 1660 r. i paryski 1763 r. Kongres berliński wprowadził do aktu z 13 lipca 1878 r. wiele postanowień, na mocy których narzucono mniejszym państwom bałkańskim zobowiązanie do czynienia różnic $\mathrm{w}$ zakresie praw politycznych pomiędzy ich poddanymi różnych wyznań ${ }^{49}$. Dopiero w XIX wieku,

48 Ibidem, s. 56-57.

49 J. Makowski, Podręcznik prawa międzynarodowego, Warszawa 1948, s. 118-119; W. J. Zaleski, Międzynarodowa ochrona mniejszości, Warszawa 1932, s. 8 i n.; 
W szczególności po procesach migracyjnych będących skutkiem I wojny światowej, zwrócono uwagę na kwestię mniejszości narodowych. Stworzony został wówczas, po zakończeniu wojny, mający charakter kompleksowy, traktatowy system ochrony mniejszości narodowych, u którego podstaw leżały jednak względy nie tyle humanitarne, co polityczne. Jakkolwiek pakt Ligi Narodów z 1919 r. nie dotykał kwestii mniejszości, to jednak od niektórych państw żądano, aby złożyły deklarację, że będą szanować prawa mniejszości ${ }^{50}$. Podstawowe sformułowania dotyczące ochrony mniejszości zostały zawarte w traktacie wersalskim, szczegółowe kwestie miały być jednak rozwiązane w specjalnych układach, z których traktat z Polską miał charakter wzorcowy. Sam traktat wersalski, jakkolwiek posługiwał się terminem „mniejszość narodowa”, to jednak nie definiował go. Próbę uściślenia tego określenia podjęto w opinii doradczej Stałego Trybunału Sprawiedliwości Międzynarodowej z 31 lipca 1930 r., sformułowanej na tle sporu dotyczącego konwencji grecko-bułgarskiej, stwierdzając, że mniejszością narodową jest ,grupa osób żyjących w danym kraju lub na danym obszarze, mających własną rasę, religię, język lub tradycje i zjednoczonych identycznością tej rasy, religii, języka lub tradycji, wyrażających się $\mathrm{w}$ poczuciu wspólnoty, a to w zachowaniu swych tradycji, utrzymywaniu wierzeń religijnych, nauczaniu i wychowa-

V. B. Bouffał, Ochrona mniejszości w Prawie Narodów, Warszawa 1928, s. 10 i n.; E. Cohen, La question juive devant le Droit international public, Paris 1922, s. 12 i n.; J. Sułkowski, The Problem of International Protection of National Minorities, New York 1944, s. 6; J. F. Duparc, Le protection des minorities de race, de langue et de religion, Paris 1922, s. 75-77; por. także S. Sierpowski, Wokót znaczenia międzywojennych koncepcji międzynarodowej ochrony mniejszości, „Sprawy Narodowościowe Seria Nowa" 1996, t. V, z. 1(8), s. 91-102; tenże, Mniejszości narodowe jako instrument polityki międzynarodowej w latach 1919-1939, Poznań 1986; tenże, Minorities in the System of the League of Nations, w: Ethnic Groups in International Relations, pod red. P. Smith, New York 1991, s. 13-37; S. Bartsch, Mindersheitenschutz in der internationalen Politik. Völkerbund und KSZE/OSZE in neuer Perspective, Opladen 1994.

50 W. Mc Kean, Equality and Discrimination unter International Law, Oxford 1973, s. 24 i n.; A. Klafkowski, Prawo międzynarodowe publiczne, Warszaw 1966, s. 191-192; W. Michnowicz, Polska wobec traktatu i procedury mniejszościowej w latach 1920-1934, ,Zeszyty Naukowe Uniwersytetu Łódzkiego. Nauki Humanistyczne" 1960, seria I, z. 15, s. 189-226; K. Kierski, Ochrona praw mniejszości w Polsce, Poznań 1933, s. 27 i n.; S. Sierpowski, Narodziny systemu ochrony mniejszości, w: Traktat wersalski z perspektywy 70 lat, Warszawa 1989, s. 52-75; A. Furier, Wersalskie źródła międzynarodowej ochrony mniejszości narodowych, „Sprawy Narodowościowe - Seria Nowa" 2001, z. 18, s. 93-108. 
niu dzieci stosownie do ducha i tradycji swojej rasy oraz wzajemnym wspieraniu się",51. Sformułowania traktatowe pozwoliły przedstawicielom doktryny na stwierdzenie, że mniejszość narodową na terytorium jakiegoś państwa może stanowić tylko zamieszkała tam stale grupa etniczna, różna od grupy podstawowej danego obszaru ${ }^{52}$. Podjęto także w literaturze próbę określenia praw mniejszości, zaliczając do nich: prawo do życia i zasadniczych, podstawowych, jednakich dla wszystkich wolności, prawa polityczne, społeczne i religijne (związane z zamieszkiwaniem w danym państwie), wreszcie prawa do własnego języka, kultury, wyznania i oświaty (te ostatnie nosiły miano praw mniejszości narodowych sensu stricto) ${ }^{53}$. Za niezwykle istotne kryterium wyróżnienia mniejszości narodowej uznawano jej liczebność (określaną procentowo lub ilościowo) w stosunku do grupy większościowej i fakt posiadania obywatelstwa kraju pobytu ${ }^{54}$. W art. 93 traktatu wersalskiego z 28 czerwca 1919 r. nałożono na Polskę obowiązek akceptowania wszystkiego, co postanowią Główne Mocarstwa Sprzymierzone i Stowarzyszone w celu zapewnienia ochrony mniejszościom rasowym, językowym lub religijnym. W efekcie doszło do zerwania w tym samym dniu tzw. traktatu mniejszościowego z Polską. Problemu ochrony mniejszości dotyczyła część III, obejmująca art. 64-158 konwencji genewskiej polsko-niemieckiej z 15 maja 1922 r. Podkreślić należy, że zobowiązania dotyczące ochrony mniejszości w systemie traktatowym Ligi Narodów miały charakter nierównoprawny. Nakładały obowiązki tylko na państwa małe i średnie, w tym nowo powstałe po I wojnie światowej oraz te, których terytorium zostało powiększone w wyniku wojny. Trzeba przy tym zauważyć, że tzw. „traktaty mniejszościowe” nie przyznawały jednostkom należącym do mniejszości narodowych żadnych bezpośrednich praw. W imieniu takich jednostek mogły działać wyłącznie wielkie mocarstwa bądź też inne państwa będące członkami Rady Ligi

51 Permanent Court of International Justice, series B, nr 17, s. 19 i 21-23.

52 J. Makowski, Podręcznik, s. 120-121.

53 C. A. Macartney, League of Nations' Protection of Minority Rights, w: The Protection of Human Rights, London 1967, s. 37 i n.

54 J. Makowski, Podręcznik, s. 118 i n.; zob. także W. Anioł, Migracje międzynarodowe a bezpieczeństwo europejskie, Warszawa 1992, s. 18-25; B. Mikołajczyk, Mniejszości prawa międzynarodowego, Katowice 1969, s. 15 i n.; C. Mik, Ochrona mniejszości narodowych w prawie europejskim, „Państwo i Prawo” 1996, z. 3, s. $19-23$. 
Narodów. Jedynie tzw. „konwencja górnośląska” z 1920 r. przyznawała jednostkom prawo kierowania bezpośrednich petycji ${ }^{55}$.

Po II wojnie światowej społeczność międzynarodowa odeszła od traktatowego systemu mniejszości narodowych, co nie oznacza, iż do problemu tego nie wracano podczas rozmaitych konferencji naukowych. Powodem odejścia od systemu traktatowego stworzonego w okresie międzywojennym był fakt, iż uznano go za nieprzydatny do rozwiązywania problemów mniejszości w Europi ${ }^{56}$. Prawa mniejszości narodowych nie zostały uregulowane w Karcie Narodów Zjednoczonych, w której ograniczono sięjedynie do stwierdzenia, że Narody Zjednoczone popierają i zachęcają ,do poszanowania praw człowieka i podstawowych swobód dla wszystkich

55 J. Żarnowski, Polska a międzynarodowy system ochrony mniejszości 1919-1934, w: Studia z najnowszej historii Niemiec i stosunków polsko-niemieckich, pod red. S. Sierpowskiego, Poznań 1986, s. 223 i n.; tenże, Dylematy mniejszościowe Ligi Narodów, „Przegląd Zachodni” 1984, nr 3, s. 31 i n.; tenże, Próby wyzyskania procedury mniejszościowej w realizacji polityki Rzeszy Niemieckiej na Bałkanach, w: Państwa bałkańskie w polityce imperializmu niemieckiego, pod red. A. Czubińskiego, Poznań 1982, s. 261 i n.; W. Michnowicz, Walka dyplomacji polskiej przeciwko traktatowi mniejszościowemu w Lidze Narodów, Łódź 1963, passim; S. Rogowski, Komisja mieszana dla Górnego Ślaska (1922-1937), Opole 1977, s. 151-152; A. Sakson, Zapisy o mniejszościach narodowych w polskich ustawach konstytucyjnych, w: Polska-Niemcy. Mniejszość niemiecka w Wielkopolsce. Przeszłość i teraźniejszość, pod red. A. Saksona, Poznań 1994, s. 181-188; F. Chrzanowski, Rozwój procedury mniejszościowej na terenie Ligi Narodów, „Strażnica Zachodnia” 1931, s. 19-25. Zob. też K. Wawruch, II Rzeczpospolita wobec mniejszości narodowych i religijnych - nowe wyzwania i oczekiwania, „Sprawy Narodowościowe - Seria Nowa” 2000, z. 16-17, s. 141-155; B. Halczak, Publicystyka narodowo-demokratyczna wobec problemów narodowościowych i etnicznych II Rzeczypospolitej, Zielona Góra 2000, s. 17 i n.

56 J. Byczkowski. Problemy mniejszości narodowych $w$ działalności ONZ, „Studia Śląskie" 1977, rok 21, s. 340; M. Suchocka, Prawa mniejszości etnicznych, religijnych i jezykowych, w: Prawa czlowieka. Model prawny, pod red. R. Wieruszewskiego, Wrocław-Warszawa-Kraków 1991, s. 143 i n.; Les droits des minorities en Europe. Vers un regime transnational, pod red. H. Miall, Paris-Montreal 1997, s. 41 i n.; M. Szczepaniak, Regulacja prawna statusu mniejszości narodowych. Wegierska propozycja wobec państw sqsiedzkich, w: Postzimnowojenna Europa. Ku jedności czy nowym podziałom?, pod red. T. Łoś-Nowak, Wrocław 1995, s. 101. Por. także R. Higgins, Minority Rights Discrepancies and Divergencies Between the International Covenaut and the Council of Europe System, w: Liber amicorum for Henry Schermers, Dordrecht 1994, s. 193; P. Thornberry, International Law and minorities, Oxford 1991 passim; N. Radley, Conceptual Problems in the Protection of Minorities. International Legal Developments, „Human Rights Quarterly” 1995, 17, s. 48. 
bez różnicy rasy, płci i języka lub religii” (art. 1 ust. 3 3 $^{57}$. Sprawa praw mniejszości miała zostać uregulowana w Powszechnej Deklaracji Praw Człowieka. Jednak także i w tej deklaracji nie doszło do sformułowania praw mniejszości narodowych. Ograniczono się tylko do stwierdzenia, że „każdy człowiek posiada wszystkie prawa i wolności zawarte w niniejszej Deklaracji, bez względu na jakiekolwiek różnice rasy, koloru skóry, płci, języka, wyznania, poglądów politycznych i innych, narodowości, pochodzenia społecznego, majątku, urodzenia lub jakiegokolwiek innego stanu. Nie wolno ponadto czynić żadnej różnicy w zależności od sytuacji politycznej, prawnej lub międzynarodowej kraju lub obszaru, do którego dana osoba przynależy, bez względu na to, czy dany kraj lub obszar jest niepodległy, czy też podlega systemowi powiernictwa, nie rządzi się samodzielnie lub jest w jakikolwiek sposób ograniczony w swej niepodległości” (art. 2) ${ }^{58}$. Wyrazem kłopotów, jakie nastręczała definicja mniejszości narodowej, jest tekst rezolucji ONZ uchwalonej jednocześnie z Powszechną Deklaracją Praw Człowieka, w której stwierdzono, że Zgromadzenie Ogólne postanawia nie poświęcać specjalnego postanowienia zagadnieniom mniejszości ,uznając, że trudno jest przyjąć jednolite rozwiązanie tak powikłanego i delikatnego zagadnienia, które posiada specyficzne aspekty w każdym państwie”. W literaturze prawno-międzynarodowej mniejszość narodową określa się jako ludność danego państwa różniącą się od większości obywateli pewnymi cechami, takimi jak: rasa, wyznanie, język, i pragnącą te cechy zachować ${ }^{59}$. Podobną definicję wy-

57 Karta Narodów Zjednoczonych, w: Międzynarodowe zobowiqzania Polski w zakresie praw człowieka. Akty prawa międzynarodowego i dokumenty KBWE, pod red. A. D. Rotfeld, Warszawa 1989, s. 10; oficjalny tekst Karty Narodów Zjednoczonych Dz. U. Nr 23, poz. 90; G. Alfredson, A. M. de Zayas, Minority Rights. Protection by the UN, „Human Rights Law Journal” 1993, s. 1 i n.

58 Powszechna Deklaracja Praw Człowieka, w: Międzynarodowe zobowiazania, s. 14. Warto zauważyć, iż Stowarzyszenie Prawa Międzynarodowego Prywatnego przyjęło w 1994 r. uchwałę, w której odnotowano, że w Powszechnej Deklaracji Praw Człowieka ,autorytatywnie rozwinięto postanowienia dotyczące praw człowieka, zawarte w Karcie Narodów Zjednoczonych”, dodając, że „wiele, jeśli nie wszystkie, praw ustanowionych w Powszechnej Deklaracji Praw Człowieka jest uznanych za normy zwyczajowego prawa międzynarodowego", zob. Raport z 66 Konferencji, Buenos Aires 1994, s. 29.

59 R. Barraine, Nouveau dictionnaire de Droit et de Sciences Economique, Paris 1974, s. 308; H. J. Schlochauer (red.), Wörterbuch des Völkerrecht, Berlin 1961, s. 527. Przy próbach zdefiniowania mniejszości koncentrowano się na niewielkiej liczbie osób tworzących takową mniejszość oraz na tym, iż zajmuje ona niedomi- 
pracowała Komisja Praw Człowieka w 1953 r., przy czym dodała, że obok tych cech mogą dochodzić inne, na podstawie których wyodrębnia się mniejszość ${ }^{60}$. P. de Ascarate, były przewodniczący sekcji Ligi Narodów, zajmującej się problemami mniejszości, sformułował własną definicję, w której zwrócił uwagę na istnienie świadomości narodowej, warunkowanej różnicami językowymi i kulturowymi, kładąc nacisk na element świadomościowy i podkreślając, że substratem mniejszości jest coś „nieuchwytnego", a równocześnie żywego, nieodpartego i dynamicznego, i trudnego do wyrażenia w słowach, a mieszczącego się w określeniu „Świadomość narodowa"61.

Próbę zdefiniowania pojęcia „mniejszość narodowa” podjęto w $1974 \mathrm{r}$. na seminarium w Ohrydzie stwierdzając, że status mniejszości narodowej posiada „grupa obywateli wystarczająca ilościowo, aby realizować cele grupy, lecz liczbowo mniejsza niż reszta ludności, połączona wspólnie więzami historycznymi, etnicznymi, kulturowymi, religijnymi lub językiem i chcąca zachować te więzy, które są różne od tych, jakie łączą resztę ludności" "62. Dalsze definicje mające służyć prawu międzynarodowemu starała się wypracować doktryna. F. Capotork w sporządzonym w 1979 r. raporcie dotyczącym praw mniejszości stwierdził, że mniejszość narodowa jest to: ,grupa liczbowo mniejsza w stosunku do reszty ludności państwa, znajdująca się w pozycji niedominującej, której członkowie - będąc obywatelami tego państwa - posiadają etniczne, religijne lub językowe cechy

nującą pozycję. Akcentowano także obiektywne istnienie pewnych cech różniących mniejszości od większości np. etnicznych, religijnych lub językowych, w połączeniu z subiektywnym życzeniem mniejszości do zachowania tych cech. Por. P. Shaw, Definition of Minorities, Oxford 1991, s. 96; także Zalecenie Rady Europy nr 1255, 1955, H/Inf 95, 3, s. 88. W literaturze podkreśla się, że Komitet Praw Człowieka w sprawie Ballantyne stwierdził, że anglojęzyczni mieszkańcy prowincji Quebec nie stanowią mniejszości, chociaż faktycznie są na tym obszarze mniejszością, gdyż mniejszość ex definitione może odnosić się do całego państwa, a nie tylko do jego części, por. „Human Rights Law Journal" 1993, s. 171-176.

60 R. Bierzanek, Współczesne stosunki międzynarodowe, Warszawa 1980, wyd. II, s. 65 .

61 P. de Ascarate, League of Nations and National Minorities an Experiment, Waszyngton 1945, s. 4.

${ }^{62}$ Seminaire sur la promotion et la protection des droits de l'homme dans les minorités nationales, ethniques et autres, Ohrid 1974, New York 1974, s. 36. Do ustaleń tej konferencji wyraźnie nawiązywał J. Barcz, tworząc własny projekt definicji. Por. J. Barcz, Definicja mniejszości narodowych, „Stosunki Międzynarodwe” 1986, nr 11, s. 91 i n. Zob. H. Suchocka, Prawa mniejszości, s. 145. 
odróżniające ich od reszty ludności i wykazująca - czasem tylko w sposób dorozumiany - poczucie solidarności nakierowane na zachowanie kultury, tradycji, religii lub języka"63. Istotnym novum tej definicji było stwierdzenie, że status mniejszości przysługuje tylko i wyłącznie obywatelom danego państwa, oraz zaakcentowanie elementu świadomościowego.

Do rozwiązania zaproponowanego przez F. Capotoriego nawiązuje definicja sformułowana przez J. Deschênesa w ramach prac Podkomisji ONZ do Walki z Dyskryminacją i Ochrony Praw Człowieka. W literaturze polskiej podkomisja ta występuje także pod nazwą: Podkomisja ONZ ds. zapobiegania dyskryminacji i ochrony mniejszości ${ }^{64}$. Według J. Deschênesa, mniejszość to „grupa obywateli państwa tworząca mniejszość liczbową i znajdująca się w niedominującej sytuacji w państwie, posiadająca etniczne, religijne lub językowe cechy, które różnią ją od większości ludności, mająca poczucie solidarności wewnątrz grupy, motywowane czasami tylko dorozumiale, kolektywną wolą przetrwania, której celem jest osiągnięcie równości faktycznej i prawnej z większością" ${ }^{65}$. Z definicji J. Deschênesa wychodzą także propozycje definicyjne wspomnianej Podkomisji, która zaproponowała, aby termin „mniejszość” odnosić wyłącznie do tych grup społecznych, które nie mają w określonym państwie charakteru dominującego i które będąc na tyle liczebne, aby mogły pielęgnować swoje tradycje i zachować odrębność, jednocześnie pragną w sposób stały utrzymać swoją odrębność etniczną, religijną lub językową. Jednocześnie Podkomisja podkreśliła, iż członkowie mniejszości muszą być lojalni względem państwa, którego są obywatelami ${ }^{66}$. Definicja J. Deschênesa zbieżna jest także z poglądami prezentowanymi w orzecznictwie Stałego Trybunału Sprawiedliwości, w myśl których na pojęcie mniejszości składa się: wyraźne wyodrębnienie grupy, rzeczywista mniejszość; rasa, religia, język, jako cechy charakterystyczne, odmienne od tych, jakie

63 F. Capotori, Étude des droit des personnes appartenant aux minorités ethnique, religienses et linguistiques, New York 1979, s. 568; także Study on the Rights of Persons Belonging to the Ethnic, Religions and Linguistic Minorities, New York 1977, s. $10 \mathrm{in}$.

64 H. Suchocka, Prawa mniejszości, s. 145-146. Odmiennie np. A. Łopatka, System międzynarodowej ochrony praw człowieka, w: Ochrona praw człowieka $w$ świecie, Bydgoszcz-Poznań 2000, s. 84.

65 Proposal concerning a definition of the term ,, minority” submitted by Mr Deschênes, „Economieand Social Council - Commision on Human Rights", E/CN/4/Sub. 2/1985, 31, s. 30.

${ }^{66}$ Ibidem, s. $18-19$. 
posiada większość; poczucie solidarności; wola zachowania wyraźnych cech odrębnych; równość prawna i faktyczna $\mathrm{z}$ większością ${ }^{67}$.

W literaturze podkreśla się, że prawa mniejszości to gwarancje, które pozwalają mniejszości zachować odrębność, a równocześnie pozwalają jej być na równym poziomie $\mathrm{z}$ większością. Powstaje przy tym problem, czy są to prawa, które zapewniają mniejszościom równość, czy też stwarzają dla nich sytuację uprzywilejowaną. Drugą sporną sprawą okazała się kwestia czy prawa mniejszości służą ochronie indywidualnej czy też grupowej $^{68}$. Jednocześnie, w trakcie prac nad Międzynarodowym Paktem Praw Obywatelskich i Politycznych, i później, w procesie wykładni norm tego aktu „odżył” istniejący dotąd głównie w płaszczyźnie socjologicznej problem stosunku terminów: „mniejszość etniczna” i „mniejszość narodowa". Było to konsekwencją faktu, iż wcześniejsze, a także późniejsze, akty prawa międzynarodowego dość niekonsekwentnie posługiwały się różnymi określeniami na oznaczenie mniejszości narodowych. Gwoli przykładu należy wskazać, że Konwencja w sprawie zapobiegania i karania zbrodni ludobójstwa z 1948 r. wspomina o grupach narodowych, etnicznych, rasowych i religijnych (art. II) ${ }^{69}$. Może to prowadzić do wniosku, że grupy narodowe są odrębne od etnicznych. Natomiast konwencja w sprawie likwidacji wszelkich form dyskryminacji rasowej z $1966 \mathrm{r}$. w art. 1 stwierdza, że ,dyskryminacja rasowa” oznacza „wszelkie zróżnicowanie, wykluczenie, ograniczenie lub uprzywilejowanie z powodu rasy, koloru skóry, urodzenia, pochodzenia narodowego lub etnicznego"70.

Przejawem trudności związanych z próbami prawniczego zdefiniowania kategorii „mniejszość etniczna” bądź „mniejszość narodowa” jest

67 Wypada zauważyć, że Stały Trybunał Sprawiedliwości Międzynarodowej (La Cour Permanente de Justice Internationale) został utworzony na podstawie art. 14 Paktu Ligi Narodów. Jego następcą jest Międzynarodowy Trybunał Sprawiedliwości (International Court of Justice) powołany na Konferencji w San Francisco 26 czerwca 1945 r. jako organ sądowy Organizacji Narodów Zjednoczonych. Oprócz zdolności rozpoznania spraw zarówno Stały Trybunał jak Międzynarodowy Trybunał były wyposażone w kompetencje doradcze. Zob. M. Iwanejko. Międzynarodowy Trybunat Sprawiedliwości, Kraków 1969, s. 67 i n.; np. orzeczenia w sprawach Niektóre niemieckie interesy na polskim Górnym Ślasku, PCIJ, seria A, nr 7, 1926.

68 E. W. Vierdag, The Concept of Discrimination in International Law, Haga 1973, s. 146; W. Mc Kean, Equality and Discrimination under International Law, Oxford 1973, s. 24; H. Suchocka, Prawa mniejszości etnicznych, s. 147-148.

69 Dz. U. 1952, Nr 2, poz. 9, sprost. Dz. U. 1952, Nr 31 poz. 213. Ratyfikowana zgodnie z ustawą z 18 lipca $1950 \mathrm{Nr}$ 36, poz. 325.

70 Dz. U. 1969, Nr 25, poz. 187. 
treść art. 27 Międzynarodowego Paktu Praw Obywatelskich i Politycznych $^{71}$. W tekście tego przepisu odstapiono od próby określenia pojęcia „mniejszość narodowa” lub „etniczna”, stwierdzając, że w państwach, „w których istnieją mniejszości etniczne religijne lub językowe, osoby należące do tych mniejszości nie mogą być pozbawione prawa do własnego życia kulturalnego, wyznawania i praktykowania własnej religii oraz posługiwania się własnym językiem wraz z innymi członkami danej grupy". Analiza tego sformułowania prowadzi do wniosku, że istnienie mniejszości w określonym państwie zależne jest od uznania tego faktu przez władze tego państwa, które muszą uznać egzystencję mniejszości w swoich granicach i przyznać jej wskazane w treści przepisy prawa. Możliwa jest oczywiście i taka sytuacja, że władze państwowe przeczą istnieniu mniejszości, którą uznaje społeczność międzynarodowa. Formy takiego uznania Pakty jednak nie przewidują. Rodzą się także wątpliwości co do zakresu użytych w treści art. 27 Paktów terminów „mniejszość etniczna”, „religijna”, ,językowa”. Niektórzy z komentatorów stanęli na stanowisku, że wszystkie wspomniane wyżej określenia odnoszą się w istocie rzeczy do mniejszości narodowych ${ }^{72}$. Inni prezentują pogląd, iż pojęcie „mniejszości narodowej” jest szersze od określenia „mniejszość etniczna"73. Za takim, szerszym, rozumieniem terminu „mniejszość narodowa" zdaje się opowiadać Rada Europy.

Już w 1949 r. Komitet do spraw Problemów Prawnych i Administracyjnych Zgromadzenia Konsultacyjnego (obecnie Parlamentarnego) Rady Europy podczas prac nad Europejska konwencja o ochronie praw człowieka i podstawowych wolności uznał, iż istnieje potrzeba zapewnienia szerszej ochrony mniejszościom narodowym ${ }^{74}$. Posługując się tym terminem, nie podjęto jednak wówczas próby jego bliższego okre-

71 Pakt ten został uchwalony przez Zgromadzenie Ogólne ONZ 16 grudnia 1966 r. Polska ratyfikowała go 3 marca 1977 r. Dz. U. 1977, Nr 39, poz. 167.

72 T. Modeen, The international Protection of National Minorities in Europe, Abo 1969, s. 108.

${ }^{73}$ Ch. Tomuschat, Protection of Minorities under Art. 27 of the Suternational Covenant on Civil and Political Rights w: Völkerrecht als Rechtsordnung Internationale Gerichtsbarkeit Menchenrechte. Festschrift für H. Mosler, pod red. R. Bernhardt, Berlin-Heidelberg-New York 1983, s. 954-966.

74 Draft Report of Committee of Experts on Human Rights to the Committee of Ministers Relating to the Rights of National Minorities, Strasburg 27 February 1973, DH/Exp./73/7, s. 1-2; B. Gronowska, Rada Europy wobec problemu mniejszości narodowych, „Sprawy Międzynarodowe” 1991, nr 10, s. 111-122. 
ślenia. Nie definiuje pojęcia mniejszości także art. 14 Europejskiej konwencji o ochronie praw człowieka i podstawowych wolności, w którym stwierdzono, że „Korzystanie z praw i wolności wymienionych w niniejszej konwencji powinno być zapewnione bez dyskryminacji wynikającej z takich powodów, jak: płeć, rasa, kolor skóry, język, religia, przekonania polityczne i inne, pochodzenie narodowe lub społeczne, przynależność do mniejszości narodowej, majątek, urodzenie bądź z jakichkolwiek przyczyn"75.

W orzecznictwie Europejskiego Trybunału Sprawiedliwości na tle art. 14 Konwencji ugruntował się pogląd, iż przepis ten nie ma samodzielnego bytu prawnego, jako że wywołuje on skutki jedynie w związku z „korzystaniem z praw i wolności" chronionych przez inne przepisy Konwencji i Protokół do Konwencji ${ }^{76}$. Jakkolwiek jeszcze przed podpisaniem wspo-

75 Dz. U. 1993, Nr 61, poz. 284.

${ }^{76} \mathrm{Na}$ takim stanowisku stawał Europejski Trybunał Praw Człowieka wielokrotnie, m.in. w decyzji z 7 listopada 2002 r. 48542/99; Henryk Zawadka przeciwko Polsce, LEX nr 56779. Dokonując wykładni art. 14 Europejskiej Konwencji Praw Człowieka, Trybunał w Strasburgu w pierwszym rzędzie musiał się odnieść do problemów związanych z używaniem swojego języka przez mniejszości narodowe. Nie wykorzystał jednak tej okazji do sformułowania próby definicji „mniejszości narodowej” bądź ,języka mniejszości”. Stwierdził jednak, że używanie swojego języka przez mniejszość narodową nie podlega żadnym ograniczeniom, z wyjątkiem tych, które dotyczą limitacji wolności wypowiedzi i są ustanowione w Europejskiej Konwencji. Stanowisko to zostało wypracowane na tle tzw. belgijskiej sprawy językowej (orzeczenie z 23 lipca 1968; A. 6, s. 34). Por. Application Nr 1474/62, „Yearbook of the European Convention of Human Rights", vol. 6, s. 332 i 340-342. Zob. także M. A. Nowicki, Europejska Konwencja Praw Człowieka. Wybór orzecznictwa, Warszawa 1999, s. 549. Zdaniem Europejskiego Trybunału, można używać języka mniejszościowego zarówno prywatnie, jak i publicznie. Interpretując dyspozycję art. 14 Europejskiej Konwencji, odwoływano się do art. 10 tegoż aktu. Warto przy tym zauważyć, że jakkolwiek sprawy takie przewijały się w orzecznictwie Europejskiego Trybunału, to jednak nie wypracowano jeszcze przekonującego, w pełni uzasadnionego stanowiska w kwestii wywieszania i wystawiania na widok publiczny napisów o charakterze prywatnym i publicznym w języku mniejszości narodowej. Zaskakujące może być także stanowisko Trybunału w sprawach nauczania w języku mniejszości narodowej. Zauważając, że prawo do pobierania nauki w języku mniejszości jest jednym z podstawowych elementów pozwalających na zachowanie tożsamości narodowej i stwierdzając, że w tym zakresie nie są dopuszczalne żadne wyjątki i ograniczenia, Trybunał jednocześnie stwierdził, że zagwarantowanie tego prawa nie pociąga za sobą żadnych pozytywnych (zwłaszcza finansowych) obowiązków państwa. Przy okazji, mając zwłaszcza w pamięci spory między Polską a Litwą oraz żądania mniejszości Polskiej na Litwie, aby nazwiska Polaków mieszkających w Republice Litewskiej i będących jej obywatelami 
mnianej Konwencji o ochronie praw człowieka i podstawowych wolności oraz później, po dokonaniu tego aktu, opracowano liczne raporty oraz sprawozdania dotykające problematyki mniejszości, a nawet wystąpiono w 1956 r. z propozycją utworzenia Europejskiego Biura do spraw Mniejszości, to jednak nie pokuszono się o próbę definicji mniejszości ${ }^{77}$. Zabrakło jej także w rekomendacji 285/1961 uchwalonej przez Zgromadzenie Parlamentarne 28 kwietnia 1961 r., którym polecono komitetowi Ministrów Rady Europy podjęcie prac nad potrzebą włączenia do Protokołu nr 2 do Konwencji Praw Człowieka odrębnego artykułu poświęconego mniejszościom narodowym i gwarantującego im także prawa, których nie obejmuje ani Konwencja, ani Protokół nr 1. Jakkolwiek sformułowano nawet projekt takiego artykułu, to jednak nie zawarto $\mathrm{w}$ nim definicji mniejszości ${ }^{78}$. W ostateczności jednak projekt ten nie został zrealizowany.

były odnotowywane w urzędowych dokumentach, zwłaszcza paszportach, aktach stanu cywilnego, dyplomach, zaświadczeniach, świadectwach i legitymacjach w brzmieniu polskim, przy użyciu polskiego alfabetu, warto zauważyć, że Konwencja ramowa o ochronie mniejszości narodowych przyjęta przez Radę Europy 1 lutego 1998 r. gwarantuje wprawdzie w art. 11 ust. 1 prawo ,używania imienia i nazwiska w języku mniejszościowym, jak również prawo do oficjalnego ich uznawania, zgodnie z przepisami prawa wewnętrznego", to jednak doktryna i praktyka jurydyczna stoją na stanowisku, iż państwo nie jest zobowiązane do zaakceptowania obcego języka w pisowni imion i nazwisk, lecz może wymagać używania alfabetu języka urzędowego w pisowni fonetycznej. $Z$ drugiej jednak strony, osoby, które zmuszone zostały do zmiany pisowni imienia lub nazwiska, mają prawo powrotu do poprzedniego. Zob. Framework Convention for the Protection of National Minorities and Explanatory Report, Council of Europe Press 1995; A. Michalska, Prawa językowe osób należacych do mniejszości narodowych. Standardy międzynarodowe, „Sprawy Narodowościowe - Seria Nowa” 1997, t. VI, z. 2(11), s. 65-77. Europejski Trybunał Praw Człowieka wielokrotnie podkreślał, że nie każde wyróżnienie lub zróżnicowanie ma cechy dyskryminacji, lecz jedynie takie, które nie ma wystarczającego uzasadnienia, prawnie dopuszczalnego celu lub nie zachowuje uzasadnionej proporcji między użytymi środkami a celem przewidzianym do osiagnnięcia. Zob. Abdulazsz, Cabales i Balkandali przeciwko Wielkiej Brytanii 28 maja 1985, A. 94; Juze przeciwko Austrii 28 października 1987, A 126; Darby przeciwko Szwecji 23 października 1990, A 187, poz 31; Radke przeciwko Holandii 21 lutego 1997, RJD 1997-1, poz.39; cyt. za M. A. Nowicki, Europejska konwencja Praw Człowieka. Wybór orzecznictwa, s. 549-550; także Rasmusen przeciwko Danii, orzeczenie z 28 listopada 1984, A. 87, cyt. za Europejski Trybunat Praw Człowieka. Orzecznictwo, t. 2, Prawa do życia i inne prawa, oprac. M. A. Nowicki, Kraków 2002, s. 1462.

77 J. Brincat, Report on the Rights of Minorities, Dok. 6294, Strasburg 1990, s. 97.

78 Recommendation 285/1961 on the Rights of National Minorities Dok. 1299, Report of the Legal Committe, Strasburg 1961, nr 1-2. 
W latach siedemdziesiątych i osiemdziesiątych Rada Europy porzuciła prace nad abstrakcyjną regulacją sytuacji prawnej mniejszości narodowych, podejmując jednak problem położenia prawnego niektórych mniejszości bądź niektórych aspektów ich sytuacji. Tych właśnie kwestii dotyczyła większość opracowanych w tym czasie raportów, rezolut cji $^{79}$ i projektów ${ }^{80}$. W trakcie tych wszystkich działań nie wypracowano jednak definicji mniejszości narodowych, co, jak podkreśla się w doktrynie, stanowić musi punkt wyjścia do prac nad przygotowaniem regulacji prawnych. Wyjątkiem jest próba definicji zaprezentowana w rekomendacji 1134/1990 Zgromadzenia Parlamentarnego w sprawie praw mniejszości, w której odnosi się to pojęcie do obywateli państwa o długim rodowodzie, eksponując element liczebności. Zakresem swoim, w myśl pkt. 11 wspomnianej rekomendacji, mniejszość narodową stanowią „oddzielne lub odróżniające się grupy, dobrze określone i zadomowione na terytorium

79 W 1978 r. po raz pierwszy zgłoszono propozycję opracowania Europejskiej Karty Praw Kulturowych Mniejszości Narodowych. W 1981 r. Zgromadzenia Parlamentarne Rady Europy przyjęło rezolucję nr 928 w sprawie problemów wychowawczych i kulturowych, rodzących się na tle języków mniejszościowych i dialektów w Europie. W treści rezolucji podkreślono konieczność opracowania karty dotyczącej języków mniejszościowych lub regionalnych. Nie podjęto jednak wówczas próby zdefiniowania pojęcia „mniejszość narodowa”. Wykonując zalecenia zawarte we wspomnianej rezolucji Stała Konferencja Władz Lokalnych i Regionalnych Europy (Standing Conference of Local and Regional Authorities of Europe - CLRAE) podjęła prace nad przygotowaniem karty. Widomym efektem jej działań była rezolucja nr 192/1988 w sprawie języków regionalnych i mniejszościowych w Europie, której towarzyszył projekt Karty. Został on (na mocy rezolucji z 16 marca 1988 r.) przekazany do zaopiniowania Zgromadzeniu Parlamentarnemu. Dla rozważań odnoszących się do kwestii mniejszości jako istotne jawi się to, że przez języki regionalne i mniejszościowe Karta rozumie języki należące do europejskiego dziedzictwa kulturowego, które są tradycyjnie używane na obszarze określonego państwa przez osoby mające jego obywatelstwo, inne od tych, które są używane przez resztę populacji, stanowiącą większość w państwie. Związanie języka z obywatelstwem powoduje, że język wietnamski, którym posługiwałaby się np. we Francji pewna, nawet dość liczna grupa uchodźców pozbawiona obywatelstwa francuskiego, nie będzie uznany za język regionalny właśnie z tej racji, że używający go nie mają obywatelstwa oraz dlatego, że nie należy on do europejskiego dziedzictwa kulturowego. (Por. Resolution 192/1988 on Regional or Minority Languages in Europe, Dok. CPL 23/8, Part I, Strasburg 1988). Kwestia praw językowych osób należących do mniejszości narodowych nie została jednak wówczas uregulowana. Rozstrzygnęła ją dopiero Konwencja umowna o ochronie mniejszości narodowych, przyjęta przez Radę Europy 1 lutego 1995 r., która weszła w życie 1 lutego 1998 r.

80 Kwestię tę kompetentnie i szczegółowo relacjonuje oraz dogłębnie analizuje B. Gronowska. Por. B. Gronowska, Rada Europy wobec, s. 113-122. 
państwa, których członkowie są obywatelami tego państwa i mają pewne religijne, językowe, kulturowe lub inne cechy charakterystyczne, odróżniające ich od większości populacji" ${ }^{\prime 81}$.

Próbę sformułowania mniejszości podjęła także Europejska Komisja Demokracji przez Prawo (European Commission on Democracy Through Law) zwana także Komisją Wenecką ${ }^{82}$. Komisja ta 8 lutego 1991 r. przed-

81 Recommendation 1134/1990 on the Rights of Minorities, Adopted on 1 October 1990, Parliamentary Assembly of the Council of Europe, Strasburg 1990. W myśl rekomendacji, mniejszości narodowe mają prawo: do uznania przez państwa, w których zamieszkują, do utrzymywania i rozwoju własnej kultury, utrzymywania własnych instytucji wychowawczych, religijnych i kulturalnych, wraz z uprawnieniami do ubiegania się o niezbędne wsparcie finansowe, a także praw do pełnego uczestnictwa w podejmowaniu decyzji dotyczących spraw mających wpływ na zachowanie i rozwój własnej tożsamości oraz w praktycznej realizacji tych decyzji. Na każdą z osób należących do mniejszości nałożono jednak obowiązki wynikające z faktu posiadania obywatelstwa lub zamieszkiwania w państwie europejskim. Rekomendacja 1134/1990 sformułowała cztery reguły minimalne dotyczące praw mniejszości, a mianowicie: równy dostęp do sądów i przyznanie praw zagwarantowanych w Europejskiej Konwencji o Ochronie Praw Człowieka i Podstawowych Wolności, przestrzeganie ogólnej klauzuli niedyskryminacyjnej, uznanie, iż szczególna sytuacja konkretnej mniejszości stosowania wobec niej szczególnych preferencji, wreszcie zagwarantowanie mniejszościom możliwości utrzymywania swobodnych i pokojowych kontaktów z obywatelami innych państw, którzy są tego samego pochodzenia lub posiadają wspólne dziedzictwo kulturowe bądź językowe.

${ }^{82}$ Komisja Wenecka została utworzona w 1990 r. z inicjatywy Rady Europy. Jest ona specjalistyczną instytucją podejmującą badania oraz wydającą opinie prawne dotyczące rozwoju i funkcjonowania instytucji demokratycznych i prawa konstytucyjnego. Ma ona charakter organu konsultacyjnego i współpracuje zarówno z państwami członkowskimi Rady Europy, jak i z tymi, które nie należą do tej organizacji. W skład Komisji Weneckiej - zwanej tak od miasta będącego jej siedzibą - wchodzą niezależni eksperci mianowani na cztery lata przez państwa członkowskie Rady Europy, które podpisały porozumienie częściowe (istotą tych porozumień jest możliwość ich podpisywania i realizacji przez ograniczony krag państw oraz założenie, iż jeśli któreś z państw zgłasza zastrzeżenie do proponowanej formy, to możliwe jest podpisanie umowy bez jego udziału). Każde z państw członkowskich deleguje jednego eksperta oraz może powołać jednego eksperta dodatkowego. Komisja spośród swoich członków powołuje na dwa lata prezydium złożone z przewodniczącego trzech wiceprzewodniczących oraz czterech członków. Celem działania Komisji jest zbliżenie europejskich systemów prawnych oraz badanie problemów związanych z funkcjonowaniem, umacnianiem i rozwojem instytucji demokratycznych w Europie. Komisja opracowuje propozycje rezolucji i projekty umów międzynarodowych. Por. European Commission for Democracy Trough Law. Annual Report of Activities for 2001, Strasburg 2002. 
stawiła projekt konwencji o ochronie mniejszości. W tekście tego aktu, zwanego czasem w literaturze konwencją wenecką, zdefiniowano mniejszości jako „grupę mniejszą liczebnie od reszty populacji państwa, której członkowie - będący obywatelami tego państwa - posiadają etniczne, religijne lub językowe cechy różne od tych charakterystycznych dla pozostałej populacji i którzy kierują się wolą zachowania własnej kultury, tradycji, religii lub języka" (art. 2). W dalszych przepisach stwierdzono, że przynależność do mniejszości powinna być sprawą indywidualnego wyboru, z którego to powodu danej osoby nie może spotkać jakakolwiek niekorzyść ${ }^{83}$. Wypada zauważyć, że Komisja Wenecka w projekcie konwencji posługiwała się terminem ,mniejszość” bez opatrywania jej przymiotnikowymi określeniami typu: „narodowa” bądź „etniczna”. (Nie zawsze jednak udawało się to w zupełności i np. w art. 2 ust. 3 projektu konwencji pojawia się termin „mniejszość narodowa” bez bliższego jednak definiowania, chyba w znaczeniu „mniejszość etniczna” bądź ,językowa”, bądź „rasowa” i w zasadzie każda, a więc w rozumieniu sensu largo.)

Wolno przypuszczać, że unikanie przymiotnika przy pojęciu „mniejszość" było pośrednim efektem sporów, jakie toczyły się w łonie różnych organów i instytucji międzynarodowych. Wyrazem ich były prezentowa-

83 Explanatory Report on the Proposal for a European Convention for the Protection of Minorities CDL91/8, Strasburg 1991, s. 6. W treści projektu konwencji zapewniono mniejszościom prawa do ochrony przed jakąkolwiek działalnością zagrażającą ich istnieniu, a także prawo do poszanowania i rozwoju etnicznej, religijnej lub językowej tożsamości. Żałować jednak należy, że nie zdefiniowano pojęcia ,rozwoju etnicznego". Członkom mniejszości zagwarantowano w treści projektu prawo do: korzystania - na zasadzie pełnej równości - z tych samych praw, jakimi cieszą się inni obywatele; utrzymywania kontaktów, także w formie kontaktów z zagranica, z innymi członkami własnej grupy; swobodnego utrzymywania, wyrażania i rozwoju kulturalnej tożsamości, używania własnego języka w życiu publicznym i prywatnym, także w kontaktach z władzami politycznymi, administracyjnymi i sądowymi - pod warunkiem, że osoby wchodzące w skład mniejszości stanowić będą znaczny procent populacji regionu lub państwa (nie sprecyzowano jednak bliżej jego wielkości); edukacji w języku macierzystym; wyrażania własnych przekonań religijnych; uzyskania stosownego i efektywnego zadośćuczynienia ze strony państwa w przypadku pogwałcenia praw mniejszości. Członkowie mniejszości - w myśl projektu - winni respektować prawo krajowe oraz prawa pozostałych obywateli państwa, w którym przyszło im żyć. Państwa powinny natomiast powstrzymywać się od prób asymilacji mniejszości, działań zmierzających do zmian proporcji populacji i powinny stwarzać mniejszościom warunki do ich udziału w sprawach publicznych. 
ne w pracach organów Wspólnot Europejskich dążenia, aby określenie „mniejszość narodowa” - jako wywołujące niezbyt pozytywne konotacje - zastapić terminem „narodowość” ${ }^{84}$. W uchwałach Parlamentu Europejskiego posługiwano się przy tym najczęściej i z wyraźnym upodobaniem określeniem „mniejszość etniczna”. Nie podjęto jednak trudu zdefiniowania ani określenia „mniejszość etniczna” ani „narodowość”.

O sformułowanie definicji mniejszości pokusił się Instrument o ochronie praw mniejszości inicjatywy środkowoeuropejskiej otwarty do podpisu w Turynie 19 listopada 1994 r. W art. 1 stwierdzono, że mniejszość narodowa oznacza „grupę liczebnie mniejszą od pozostałej części ludności w danym państwie, której członkowie, będący obywatelami danego państwa, mają etniczne religijne i językowe cechy odróżniające ich od pozostałej części ludności i kierują się wolą zachowania własnej tradycji, religii i języka" ${ }^{95}$. Zauważyć jednak należy, iż definicja ta wymaga, aby różnice pomiędzy mniejszością narodową a pozostałą częścią populacji państwa sprowadzały się nie tylko do elementów etnicznych - których zresztą bliżej nie zdefiniowano - lecz także religijnych i językowych. Z tekstu przypisu wynika, że wystapienie tylko jednego spośród powyższych warunków nie daje podstaw do wyróżnienia mniejszości. W praktyce mogą tu wystapić poważne trudności, np.: ludność polska na Litwie różni się niewątpliwie etnicznie i językowo od reszty populacji tego kraju, ale nie religijnie. Ludność Irlandii Północnej od Anglików różni jedynie religia i mgliste przekonanie o odrębności etnicznej.

Pamiętać należy, że dla niektórych państw Europy Zachodniej, problemem mogą być grupy etniczne imigrantów, najczęściej mieszkańców byłych kolonii. O to, czy mają one charakter „mniejszości etnicznych” bądź „mniejszości narodowych”, toczą się w tych państwach poważne spory, głównie o charakterze politycznym, ale mające, co naturalne, także wymiar prawny i socjologiczny ${ }^{86}$.

Problem ochrony mniejszości narodowych podjęła ostatnio Konwencja ramowa o ochronie mniejszości narodowych sporządzona w Strasbur-

84 Documents of the Commission of the European Communnities, Roma 1986, s. 28. Por. J. Sozański, Ochrona mniejszości, s. 24-26.

85 J. Janusz, P. Bajda, Ochrona mniejszości. Standardy europejskie, Warszawa 2000, s. 61; J. Sozański, Ochrona mniejszości, s. 24.

${ }^{86}$ J. Sozański, Ochrona, s. 24-25; S. Castles, M. J. Miller, The Age of MigrationInternational Population Movements in the Modern World, London 1998, s. 58. 
gu 1 lutego 1995 r. ${ }^{87}$ Asumptem do przyjęcia większości rozwiązań Konwencji ramowej było uchwalenie w 1993 r. przez Zgromadzenie Parlamentarne rezolucji zalecającej Komitetowi Ministrów przyjęcie protokołu dodatkowego do Europejskiej Konwencji Praw Człowieka. Protokół ten miał dotyczyć ochrony praw mniejszości. Integralną częścią wspomnianej rezolucji był projekt takowego protokołu dodatkowego. W treści tego protokołu sformułowano projekt definicji terminu „mniejszość narodowa". Został on wyraźnie oparty na rozwiązaniach przyjętych dla określenia „mniejszości” w projekcie konwencji wiedeńskiej. W myśl projektu protokołu, mniejszość narodowa miała oznaczać „grupę osób w państwie, które: a) zamieszkują na terytorium państwa i mają jego obywatelstwo; b) związane są z państwem w sposób ustabilizowany i trwały; c) odróżniają się od reszty populacji specyficznymi cechami etnicznymi, kulturowymi, religijnymi lub językowymi; d) pozostając mniejszością w skali państwa i w skali regionu, grupy te są wystarczająco liczebne; e) mają wolę utrzymania swej tożsamości, zwłaszcza w dziedzinie kultury, tradycji religii lub języka. Definicja ta wywołała jednak sprzeciw wielu państw i podczas wiedeńskiej Konferencji Szefów Państw i Rządów Krajów Członkowskich Rady Europy odrzucono propozycję protokołu dodatkowego, podejmując decyzję o przygotowaniu konferencji ramowej" ${ }^{\prime 8}$.

W preambule Konwencji ramowej stwierdzono m.in., że ,pluralistyczne i prawdziwie demokratyczne społeczeństwo powinno nie tylko szanować etniczną, kulturalną, językową i religijną tożsamość każdej osoby należącej do mniejszości narodowej, lecz także tworzyć odpowiednie warunki pozwalające im wyrażać, zachowywać i rozwijać tę tożsamość". Nawiązano też do zasad i zobowiązań odnoszących się do ochrony mniejszości narodowych, zawartych w konwencjach i deklaracjach Narodów Zjednoczonych oraz w dokumentach Konferencji Bezpieczeń-

87 Konwencja została ratyfikowana przez Polskę 10 listopada 2000 r. Dz. U. 2002, $\mathrm{Nr} 22$, poz. 209. Czytelnika nie legitymującego się wykształceniem prawniczym może dziwić nieco tytuł Konwencji. Oczywiście, że tak jak każda inna konwencja nakłada ona na państwa, będące jej stronami, zobowiązania prawnomiędzynarodowe. Różnica między konwencją ramową a innymi konwencjami polega na tym, że ta pierwsza ustanawia ogólne zasady, pozostawiając państwom wybór środków dla ich realizacji oraz margines swobody w doborze metod wykonania zobowiązań międzynarodowych. Normy konwencji ramowej nie mogą też być bezpośrednio stosowane w krajowym porządku prawnym i wymagają sprecyzowania w ustawodawstwie.

${ }^{88}$ A. Michalska. Rada Europy w obronie mniejszości narodowych, ,Sprawy Międzynarodowe - Seria Nowa" 1996, t. V, z. 1(8), s. 88. 
stwa i Współpracy w Europie, zwłaszcza do dokumentu kopenhaskiego z 29 czerwca 1990 r. W obszernej, jak na tego typu dokument, liczącej 32 artykuły konwencji sformułowano wobec państw wiele zobowiązań prawno-międzynarodowych, wśród nich m.in. zakaz prowadzenia polityki przymusowej asymilacji, zakaz dyskryminacji oraz obowiązek czuwania nad rozwojem tolerancji i dialogu międzykulturowego. Osobom należącym do mniejszości narodowych konwencja gwarantuje zarówno to, że swobodnie będą mogły podjąć decyzję o tym, że należą, bądź nie należą, do mniejszości, jak i to, że nie pociągnie to za sobą niekorzystnych dla nich skutków. Przedstawicielom mniejszości omawiana konwencja gwarantuje prawo do organizowania zgromadzeń, swobodnego stowarzyszania się, a także wolność wyrażania opinii, wolność myśli, sumienia i wyznania. Przedstawiciele mniejszości zgodnie z treścią konwencji mają też prawo do otrzymywania i przekazywania informacji i idei w języku mniejszości bez ingerencji władz publicznych i bez względu na granice państwowe, nie mogą też być dyskryminowane w dostępie do środków przekazu. Państwa zobowiązane są uznać to, że każda osoba należąca do mniejszości ma prawo do swobodnego używania bez jakiejkolwiek ingerencji, swojego języka, będącego językiem mniejszości, zarówno prywatnie, jak i publicznie, ustnie oraz pisemnie. Na obszarach zamieszkałych tradycyjnie lub w znaczącej liczbie przez przedstawicieli mniejszości państwa, będące stronami Konwencji ramowej, zapewnią osobom należącym do tej mniejszości możliwość porozumiewania się w języku mniejszości z organami administracyjnymi. Państwa będące stronami konwencji zobowiązały się uznać, że każda osoba należąca do mniejszości narodowej ma prawo do używania swego nazwiska i imienia w języku mniejszości oraz do oficjalnego uznania przyjęcia tego brzmienia zgodnie $\mathrm{z}$ trybem przyjętym w ustawodawstwie konkretnego państwa. W rejonach zamieszkałych przez znaczącą liczbę osób należących do mniejszości narodowej (pojęcie znaczącej większości wydaje się dalece nieostre) państwa będące stronami konwencji zobowiązały się podjąć starania, aby zgodnie z obowiązującym prawem i umowami międzynarodowymi umieszczać również w języku mniejszości tradycyjne nazwy lokalne, nazwy ulic i inne oznakowania topograficzne o charakterze publicznym, o ile istnieje na to wystarczające zapotrzebowanie.

Państwa będące stronami omawianej konwencji zostały także zobowiązane do podjęcia w celu upowszechnienia wiedzy o kulturze, historii, języku i religii, zarówno mniejszości jak i większości populacji. Zobowiązały się one także popierać równy dostęp mniejszości narodowych do oświaty na wszystkich poziomach oraz do uznania praw osób należących 
do mniejszości do zakładania i prowadzenia własnych, prywatnych instytucji oświatowych i szkoleniowych, co nie może jednak pociagnąć za sobą dla państwa zobowiązań finansowych. Osobom należącym do mniejszości narodowych zagwarantowano prawo do nauki ich języka. W rejonach zamieszkałych tradycyjnie lub przez znaczącą liczbę osób należących do mniejszości narodowych państwa będące stronami konwencji mają się starać zapewnić, o ile będzie na to wystarczające zapotrzebowanie i o ile będą miały możliwości w ramach swoich systemów oświatowych, odpowiednie warunki do uczenia się języka mniejszości lub nauki w tym języku. Nie może to jednak stworzyć uszczerbku dla nauki języka oficjalnego lub nauczania w tym języku. Państwa zobowiązały się także powstrzymać od stosowania środków zmieniających proporcje ludnościowe w rejonach zamieszkałych przez osoby należące do mniejszości narodowych oraz działań mających na celu ograniczanie praw i wolności tej ludności. Na członków mniejszości nałożono obowiązek respektowania ustawodawstwa krajowego oraz praw innych osób należących do większości lub innych mniejszości narodowych.

Konwencja ramowa nie zawiera definicji mniejszości narodowej, dlatego też Polska, ratyfikując tę konwencję, oświadczyła, że pod terminem mniejszość narodowa rozumie „mniejszości narodowe zamieszkałe na terytorium Rzeczypospolitej Polskiej, której członkowie są obywatelami polskimi". Tego rodzaju stwierdzenie razi pleonazmem i, praktycznie rzecz biorąc, wyjaśnia jedynie to, iż Polska chce respektować prawa mniejszości w stosunku do tych rzeczywistych przedstawicieli mniejszości, którzy są jej obywatelami. Tak więc, do licznych grup ludności wietnamskiej bądź czeczeńskiej, których przedstawiciele nie posiadają, najczęściej z natury rzeczy, obywatelstwa polskiego, nie będą mogły mieć zastosowania przepisy Konwencji ramowej. Zauważyć należy, że problemu mniejszości narodowej nie definiuje także rozporządzenie Ministra Edukacji Narodowej i Sportu z 3 grudnia 2002 r. w sprawie warunków i sposobu wykonywania przez szkoły i placówki publiczne zadań umożliwiających podtrzymywanie poczucia tożsamości narodowej, etnicznej, językowej i religijnej uczniów należących do mniejszości narodowych i grup etnicznych ${ }^{89}$.

Zauważyć należy, że prace dotyczące problematyki mniejszości narodowych nie zostały zakończone zarówno w obszarze systemu uniwersal- 
nego, jak i europejskiego oraz wspólnotowego. Mimo, że niewątpliwie następuje proces integracji co najmniej w płaszczyźnie europejskiej, to jednak problem mniejszości i jej praw wydaje się nadal żywy. Jest rzeczą paradoksalną, iż mimo procesu integracyjnego, a może właśnie dzięki niemu, pojawiają się roszczenia coraz to nowych grup ludności pragnących uchodzić za mniejszości narodowe i pretendujące do tego miana. Jakkolwiek pojawiają się coraz to nowe metody regulacji kwestii mniejszościowych, coraz to nowe rezolucje Zgromadzenia Ogólnego ONZ bądź Komisji Praw Człowieka, to społeczność międzynarodowa ciagle nie może zgodzić się na sformułowanie pełnej, nie budzącej wątpliwości definicji mniejszości. Głównym problemem spornym jest w tym względzie kwestia, czy prawa mniejszości przysługują obywatelom danego państwa, czy także osobom pozbawionym tego obywatelstwa, czy są to osoby związane z państwem od dawna w sposób trwały i ustabilizowany, wreszcie to, czy i na ile musza się one odróżniać od reszty populacji, w szczególności, czy konieczne jest odróżnienie kulturowe, religijne, językowe i etniczne występujące jednocześnie, czy też może wystarczy jeden $\mathrm{z}$ tych elementów ${ }^{90}$.

Zauważyć należy, że traktaty dwustronne, także te podpisywane przez Polskę, a dotyczące problematyki mniejszościowej nie zawierają definicji mniejszości.

\section{Summary}

The problem of national minorities appears to be quite a controversial issue. This is so because it is considered by lawyers, sociologists, culture researchers, historians and political scientists. It is not a trivial matter in the controversies caused by this problem

${ }^{90}$ Wspomniane akty prawne analizuje kompetentnie i szczegółowo J. Sozański, Ochrona mniejszości, passim; por. także S. Łoziński, Polskie regulacje prawne dotyczace mniejszości narodowych i cudzoziemców na tle zasad polityki wielokulturowości, „Sprawy Narodowościowe - Seria Nowa” 1999, z. 14, s. 81-100; C. Mik, Metody regulacji kwestii mniejszościowej w prawie międzynarodowym $i$ w prawie polskim, „Sprawy Narodowościowe - Seria Nowa” 1994, t. III, s. 25-39; odnośnie aktów prawa międzynarodowego zob. K. Kwaśniewski, Instytucjonalizacja ochrony praw mniejszości, „Sprawy Międzynarodowe - Seria Nowa” 1997, t. VI, z. 1(10), s. 259-261; zbiór aktów prawnych dotyczących mniejszości przynosi książka Ochrona praw osób należacych do mniejszości narodowych, pod red. S. Łozińskiego, Warszawa 1996, niestety, jak wykazała w recenzji A. Michalska, opracowanie to zawiera wiele błędów i niedociagnięć (A. Michalska, Przepisy prawne o mniejszościach narodowych, „Sprawy Narodowościowe - Seria Nowa” 1996, t. V, z. 2(9), s. 205-210). 
that it is related to a particularly sensitive political area that in political practice generates immense problems and brings about conflicts.

The paper attempts to group the definitions developed by sociology and political science and to demonstrate the most controversial elements. The problem of national minorities is related to the notions of nation, nationality, ethnic minority and ethnographic minority.

The main emphasis falls on the legal approach as the attempts at developing a legal definition (i.e. the definition stipulated by the act of law) are traced while acknowledging that such a definition has not been developed although numerous acts of international law concern the issues of minorities. 